\title{
The structure and kinematics of the central Taiwan mountain belt derived from geological and seismicity data
}

\author{
D. Brown, ${ }^{1}$ J. Alvarez-Marron, ${ }^{1}$ M. Schimmel, ${ }^{1}$ Y.-M. Wu, ${ }^{2}$ and G. Camanni ${ }^{1}$ \\ Received 17 May 2012; revised 17 September 2012; accepted 20 September 2012; published 27 October 2012.
}

[1] The structure of the Taiwan mountain belt is thought to be that of an imbricate thrust and fold belt developed in a forward breaking sequence above a shallowly dipping basal detachment. In recent years, however, a growing amount of seismicity data from the internal part of the mountain belt indicates the existence of widespread fault activity in the middle and lower crust, suggesting that deeper levels of the crust must be involved in the deformation than predicted by the shallow detachment, imbricate thrust belt model.

To address this issue, we present new geological mapping, together with earthquake focal mechanism and seismic energy release data from the central part of Taiwan. We concur with the interpretation that the foreland basin part of the Western Foothills comprises an imbricate thrust system that is developing as a forward breaking sequence that is structurally and kinematically linked to a basal detachment at between 7 and $10 \mathrm{~km}$ depth. To the east of the foreland basin, however, in the Hsuehshan and Central Ranges, our data show the presence of two fault systems. An earlier, inactive thrust system with a well-developed cleavage is cut by a system of steeply dipping active faults that penetrate to a depth of 25 to $30 \mathrm{~km}$ or more. In the Hsuehshan Range, the second fault system is best represented by a structural and kinematic model in which this part of the mountain belt forms a zone of transpression with a structural architecture similar to that of a crustal-scale positive flower structure. Eastward, in the Central Range, Mesozoic basement rocks are over thrusting strongly folded and cleaved deep water sediments of the first, now inactive, thrust system. The involvement of deep crustal levels and Mesozoic basement in the second fault system is suggestive of the reactivation of preexisting basin-bounding faults that were located on the Eurasian continental margin.

Citation: Brown, D., J. Alvarez-Marron, M. Schimmel, Y.-M. Wu, and G. Camanni (2012), The structure and kinematics of the central Taiwan mountain belt derived from geological and seismicity data, Tectonics, 31, TC5013, doi:10.1029/2012TC003156.

\section{Introduction}

[2] The structure of the faulted and folded rocks involved in the Taiwan mountain belt (Figure 1) is often presented as an imbricate thrust and fold belt developed in a forward breaking sequence above a shallow, east dipping basal detachment [Suppe, 1980, 1981; Ding et al., 2001; Carena et al., 2002; Yue et al., 2005; Malavieille and Trullenque, 2009]. The bulk of the data for this interpretation of the structure come from surface geological observations, shallow reflection seismics, and borehole data along the western flank of the mountain belt, in what is known as the Western Foothills [Suppe, 1981; Namson, 1981; Mouthereau et al., 2001, 2002; Hickman et al., 2002; Yue et al., 2005]

\footnotetext{
${ }^{1}$ Instituto de Ciencias de la Tierra "Jaume Almera," CSIC, Barcelona, Spain.

${ }^{2}$ Department of Geosciences, National Taiwan University, Taipei, Taiwan.

Corresponding author: D. Brown, Instituto de Ciencias de la Tierra "Jaume Almera", CSIC, Lluis sole i Sabaris s/n, ES-08028 Barcelona, Spain. (dbrown@ictja.csic.es)

Published in 2012 by the American Geophysical Union.
}

(Figure 1). The more internal part of the mountain belt is less well understood because of difficult access in this area of high, rugged topography and heavy forest cover. Nevertheless, collapsing [Jones and Stewart, 1997] and selective picking of relocated small-magnitude (between $M_{L} 1$ and 4) earthquake hypocenter data appear to validate the interpretation of extending a detachment from beneath the Western Foothills across the entire mountain belt in central Taiwan [Carena et al., 2002]. Combining the seismicity data with surface geological data from published geological maps from the Western Foothills and the western part of the Hsuehshan Range (see section 2.1), Yue et al. [2005] have also interpreted the Taiwan mountain belt to have developed in a forward breaking sequence above a basal detachment that extends eastward, with ramps and flats, beneath the entire mountain belt. In this latter interpretation, the more internal units are structurally linked to the basal detachment, forming three imbricate thrust sheets with the largest of these, the Tili thrust sheet, transporting nearly the entire Taiwan mountain belt several tens of kilometers westward [see Yue et al., 2005, Figure 16]. Other orogen-scale structural interpretations [e.g., Malavieille and Trullenque, 2009] have added faults and complexities, but maintain the forward 


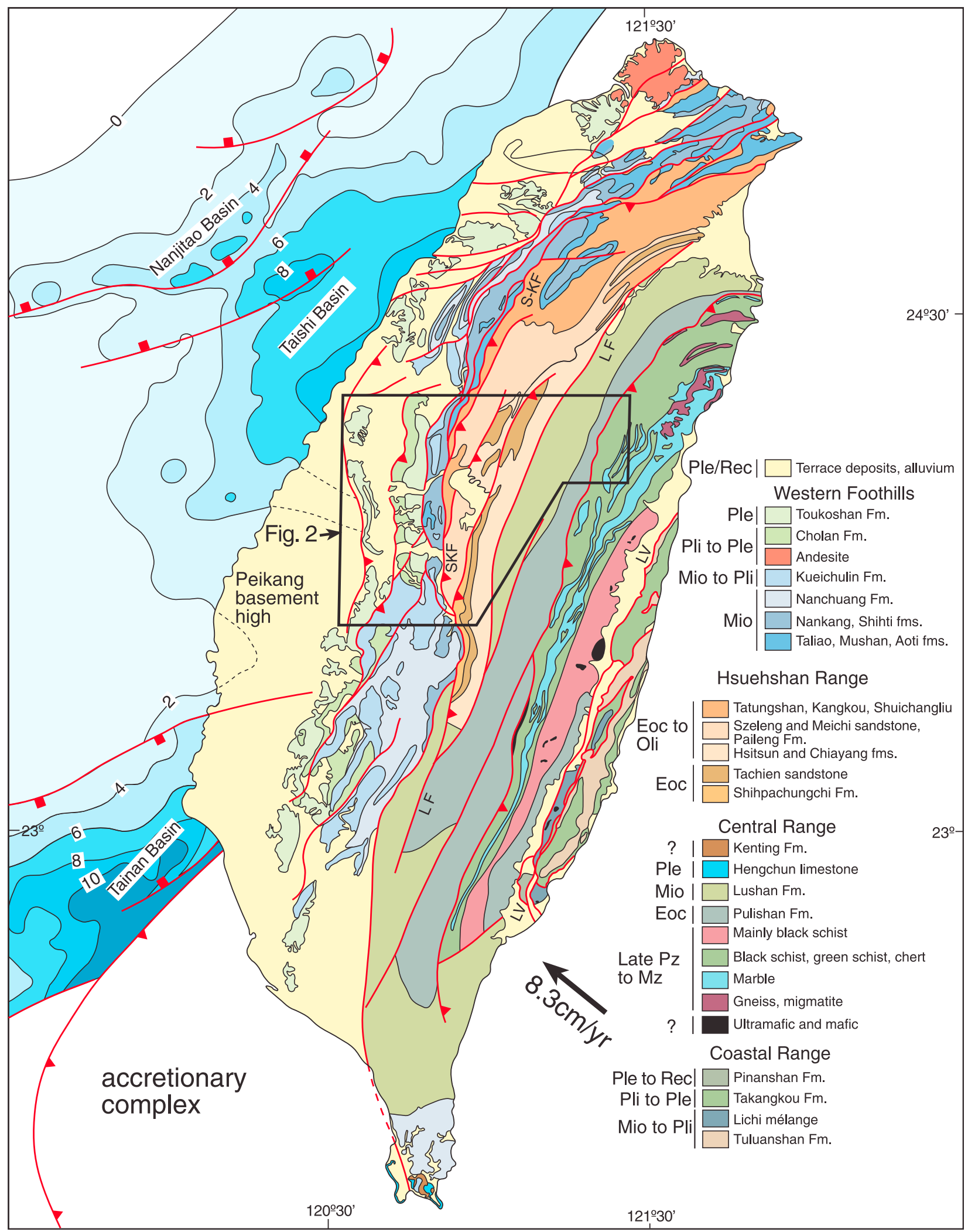

Figure 1. Geological map of Taiwan [after C.-H. Chen et al., 2000]. The basin morphology and structure in the Taiwan Strait is from Teng and Lin [2004]. Contours denote the thickness of the Cenozoic sediments in the basins. Note the orientation of the basin-bounding faults relative to the convergence vector $\left(8.3 \mathrm{~cm} / \mathrm{yr}\right.$ toward $\mathrm{N} 49^{\circ} \mathrm{W}$ [Yu et al., 1997]). The location of the Peikang basement high is shown, as is that of Figure 2. SKF $=$ Shuilikeng fault, $\mathrm{LF}=$ Lishan fault, $\mathrm{LV}=$ Longitudinal Valley. Ple/Rec $=$ Pleistocene/Recent, $\mathrm{Pli}=$ Pliocene, $\mathrm{Mio}=$ Miocene, $\mathrm{Eoc}=$ Eocene, $\mathrm{Pz}=$ Paleozoic, $\mathrm{Mz}=$ Mesozoic . 
breaking imbricate thrust system with a shallowly dipping, throughgoing basal detachment.

[3] There is, however, a growing amount of geophysical data from the internal part of the mountain belt that indicates widespread fault activity in the middle and lower crust, well below the level of the proposed detachment [Wu et al., 1997, 2004; Gourley et al., 2007; Mouthereau and Lacombe, 2006; Kaus et al., 2008; Mouthereau et al., 2009; Yamato et al., 2009; Bertrand et al., 2009, 2012; Wang et al., 2010; Kuo-Chen et al., 2012]. For example, recent magnetotelluric experiments show a prominent electrical conductor that extends into the middle crust, crossing the proposed detachment [Bertrand et al., 2009, 2012]. Similarly, analyses of seismicity data also indicate that there are several steeply dipping faults that penetrate into the middle and perhaps even the lower crust [e.g., Wu et al., 1997, 2004; Gourley et al., 2007]. On the basis of these data, it has been suggested that any model for the structural architecture of the Taiwan mountain belt needs to incorporate a number of steeply dipping active faults that involve nearly the entire crust $[W u$ et al., 1997, 2004; Gourley et al., 2007; Mouthereau and Lacombe, 2006; Kaus et al., 2008; Yamato et al., 2009; Bertrand et al., 2009, 2012]. A corollary to this is that these faults would have to disrupt any forward breaking sequence and cut the basal detachment proposed in the imbricate fold and thrust belt model. This proposal therefore has significant implications for the geometric, mechanical and kinematic evolution of the Taiwan mountain belt that are very different from what has so far been presented on the basis of the imbricate thrust belt model.

[4] While seismicity, GPS, and thermochronological data can provide significant insights into the kinematics and mechanics of the Taiwan mountain belt, in order to further advance our understanding of the structures and the kinematics that provide the first-order constraints on these types of data, much more surface geology data are needed from its interior. In this paper we present new geological mapping in the central part of Taiwan which spans nearly the entire width of the mountain belt (Figure 1). These geological data are used to propose a revised stratigraphic scheme for the Hsuehshan Range and to determine the regional structural geology from which geometically constrained cross sections are constructed. These data are then integrated with earthquake focal mechanism and seismic energy release data to place constraints on a model for the structural architecture and kinematics of this part of the mountain belt that takes the relative deformation sequence and the deep seismicity into account. Details of the methodologies used in each of these steps are below. These data and the model interpreted from them are then discussed in relation to other local- and regional-scale structural and kinematic interpretations.

\section{Geological Background}

\subsection{Tectonostratigraphic Zones}

[5] The Taiwan mountain belt is divided into four roughly N-S oriented tectonostratigraphic zones that are separated by major faults (Figures 1 and 2). From west to east these zones are; the Western Foothills, the Hsuehshan Range, the Central Range, and the Coastal Range. The Western Foothills, Hsuehshan Range, and Central Range are forming as the result of deformation and uplift of Eocene to Miocene sediments and older continental margin rocks of Eurasia and the latest Miocene and younger synorogenic sediments in the foreland basin [e.g., Suppe, 1980; Yue et al., 2005; Mouthereau et al., 2001]. The Western Foothills form the frontal part of the mountain belt and is juxtaposed against the Hsuehshan Range along the Shuilikeng fault. To the east, the Hsuehshan Range is juxtaposed against the Central Range along the Lishan fault. The Coastal Range is composed of volcanic rocks and sedimentary basins of the Luzon arc, which is being thrust obliquely over the Eurasian margin along the Longitudinal Valley fault [e.g., Yu and Kuo, 2001; Chen et al., 2007; Shyu et al., 2008]. Below we give an overview of the outcropping stratigraphy of the Western Foothills, Hsuehshan Range, and the western part of the Central Range.

\subsection{Stratigraphy}

[6] The stratigraphy of the outcropping Eurasian continental margin in central Taiwan can be broadly divided into Permian to Cretaceous prerift clastic sediments, marble, and metaigneous rocks (which we here call basement), Eocene synrift clastic sediments that are unconformably overlain by early Oligocene clastics [e.g., Chiu, 1975; Ho, 1988; Teng, 1992; Jahn et al., 1992; Shaw, 1996; Huang et al., 1997, 2001; Lin et al., 2003; Teng and Lin, 2004]. The Oligocene unconformity is interpreted to represent the rift-to-drift transition, or breakup unconformity [e.g., Teng, 1992; Huang et al., 1997, 2001; Lin et al., 2003; Teng and Lin, 2004]. The Oligocene is overlain by Miocene platform margin to slope clastic sediments which are in turn overlain by latest Miocene to Holocene synorogenic clastics of the foreland basin to the Taiwan mountain belt [e.g., Chiu, 1975; Ho, 1988; Teng, 1992; Shaw, 1996; Huang et al., 1997, 2001; Lin et al., 2003; Teng and Lin, 2004]. Below, the outcropping stratigraphy of each tectonostratigrapic zone is presented.

[7] The outcropping stratigraphy of the Western Foothills consists of Eocene through Miocene clastic sediments of the Eurasian platform margin and latest Miocene to Pliocene through Holocene synorogenic sediments [e.g., Teng, 1992] (Figures 2 and 3). The oldest unit that outcrops comprises volcanic rocks of the Tsukeng Formation. This formation was previously assigned either an Eocene or Oligocene age, but recent studies of large foraminifera and $\mathrm{U}-\mathrm{Pb}$ dating of zircons from an ash layer at the top of the sequence indicates that it is late middle Eocene in age (C-Y. Huang, personal communication, 2012). A borehole through the Tsukeng Formation encountered Eocene age rocks of the Paileng Formation (see below) [Chiu, 1975]. The Tsukeng Formation is unconformably overlain by Miocene age, mostly shallow water clastic deposits, although some authors claim that the Oligocene Shuichangliu Formation is found above the Tsukeng Formation [e.g., Chiu, 1975; Ho, 1988]. In the study area, the Miocene can be broadly divided into four sedimentary sequences, each of which begins with a thickbedded sandstone unit at the base and is overlain by thinbedded sandstone (locally thick beds) and shale. Because of differences in the naming and discrimination of individual formations between the 1:50,000 geological maps in the study area, in this paper we define the following four sequences (Figure 3). The early Miocene Takeng Formation is approximately 800 to $1000 \mathrm{~m}$ thick and is overlain by the 


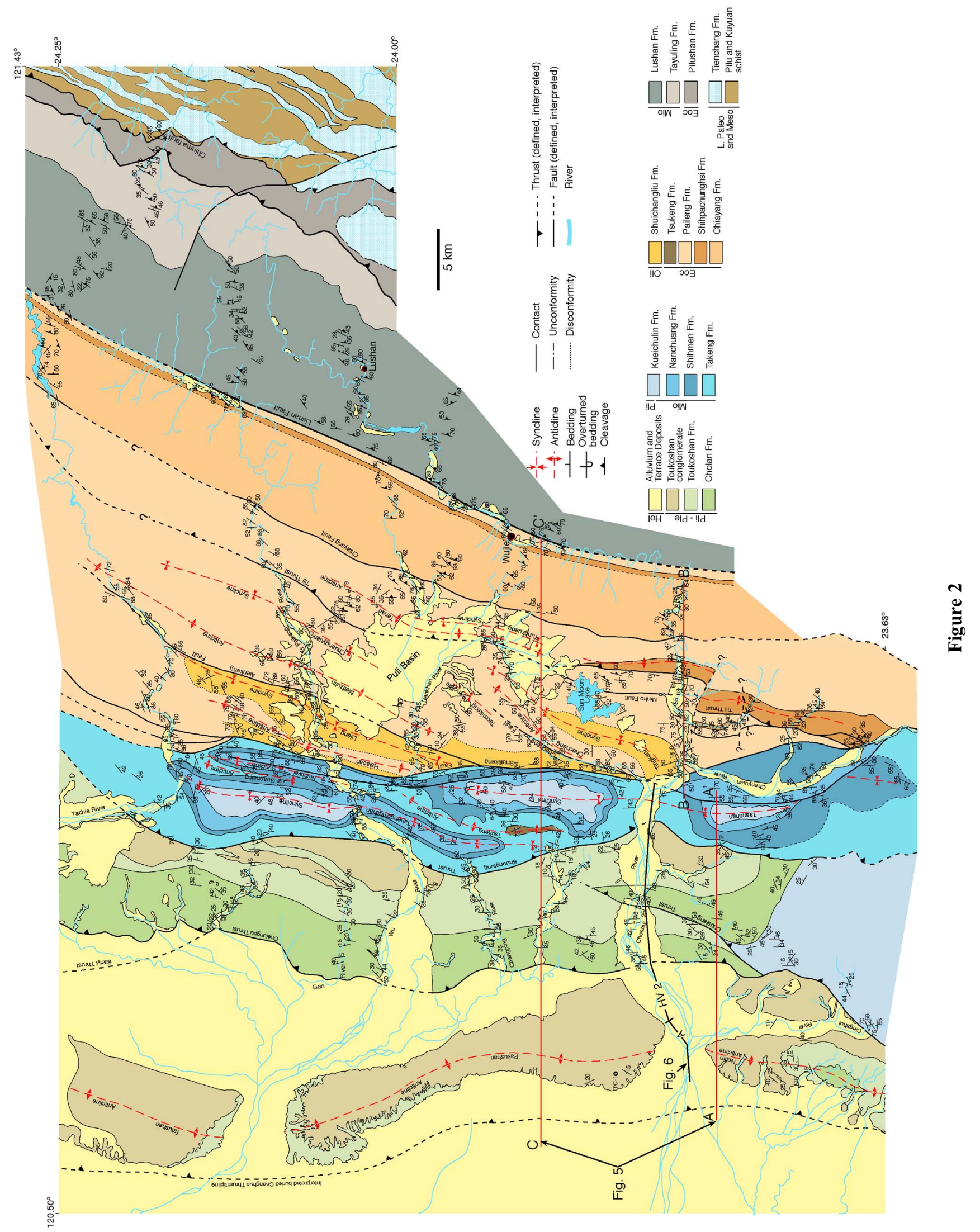




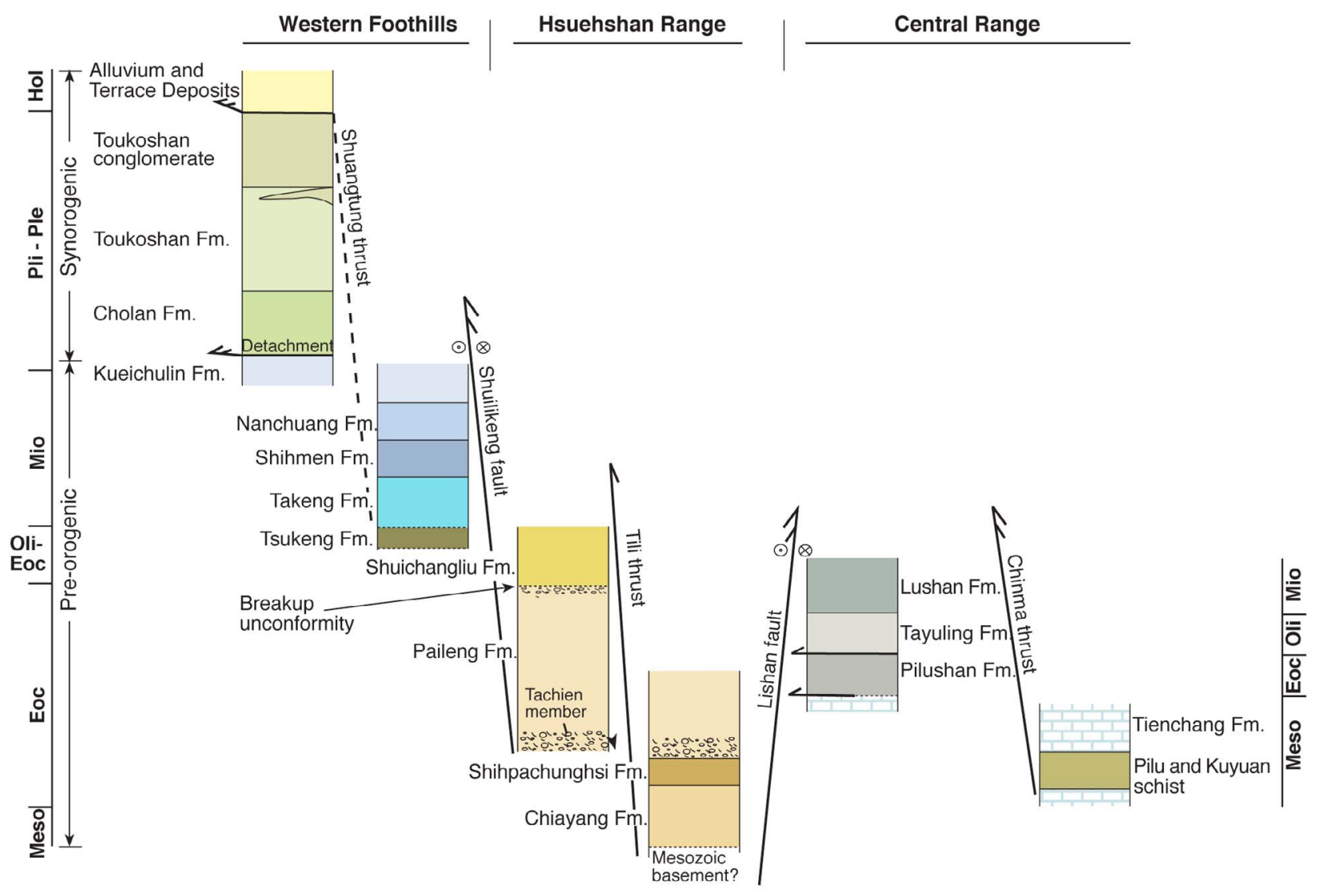

Figure 3. Schematic tectonostratigraphic columns for the outcropping geology of the different zones in central Taiwan. The preorogenic and synorogenic units are indicated for the Western Foothills and the Hsuehshan Range, as is the breakup unconformity. Note that the ages of the formations in the Central Range are a different scale. Faults with a single arrow head are D1, and those with a double arrow head are D2 (see section 5.2 for discussion of these two sequences of deformation).

up to $500 \mathrm{~m}$ thick Shihmen Formation, which is in turn overlain by the $\sim 250 \mathrm{~m}$ thick Nanchuang Formation. The Nanchuang Formation is conformably overlain by the latest Miocene to early Pliocene Kueichulin Formation. There is some discussion as to whether the Pliocene age upper part of the Kueichulin Formation or the overlying Pliocene Chinshui shale is the first synorogenic sedimentary unit to appear in the foreland basin [e.g., Teng, 1987; Covey, 1986]. The Chinshui shale comprises a several hundred meter thick member at the base of the Pliocene to Pleistocene Cholan Formation. The Cholan Formation comprises approximately $2.5 \mathrm{~km}$ of interbedded mudstone, shale, and sandstone. The Cholan Formation is conformably overlain by the Pleistocene Toukoshan Formation, a coarsening upward sequence made up of thick-bedded sandstone with shale interbeds that, upward, becomes interfingered with, and eventually completely replaced by, conglomerate. In parts of the map area, the Toukoshan Formation may reach up to $5 \mathrm{~km}$ in thickness. The Toukoshan Formation is overlain by Holocene age gravels that, in places, are several hundred meters thick.
[8] The stratigraphy of the Hsuehshan Range in the study area is complicated by a complex structure and the almost complete lack of fossils. While the rocks in the Hsuehshan Range are assigned an Eocene and Oligocene age [e.g., Ho, 1988], in light of new structural and fossil data (see below) [Chen et al., 2009], the stratigraphic sequence accepted up to now [e.g., Ho, 1988; Lo and Yang, 2002, C.-Y. Huang et al., 2000] appears to have a number of problems. In this paper, we propose a new stratigraphic scheme that has arisen from our mapping in which the oldest stratigraphic unit is the Chiayang Formation (Figure 3). The Chiayang Formation begins with a sequence of thick-bedded sandstone at its base (the Yushan member), followed by an unknown thickness of strongly folded shale with a penetrative cleavage. It is not clear what lies below the Chiayang Formation since it is everywhere in fault contact with the rocks to the west. The Shipachungchi Formation is interpreted to overlie the Chiayang Formation, although the contact is not exposed. It is composed of several hundred meters of thin-bedded sandstone and mudstone. It is in turn overlain by the Paileng

Figure 2. Geological map of the study area in central Taiwan. The locations of the cross sections in Figure 5 and the seismic lines in Figure 6 are shown. A larger-scale version of this map is provided in Figure S1. Ple/Rec $=$ Pleistocene/Recent, $\mathrm{Pli}=$ Pliocene, $\mathrm{Mio}=$ Miocene, Eoc $=$ Eocene, $\mathrm{Pz}=$ Paleozoic, $\mathrm{Mz}=$ Mesozoic . 


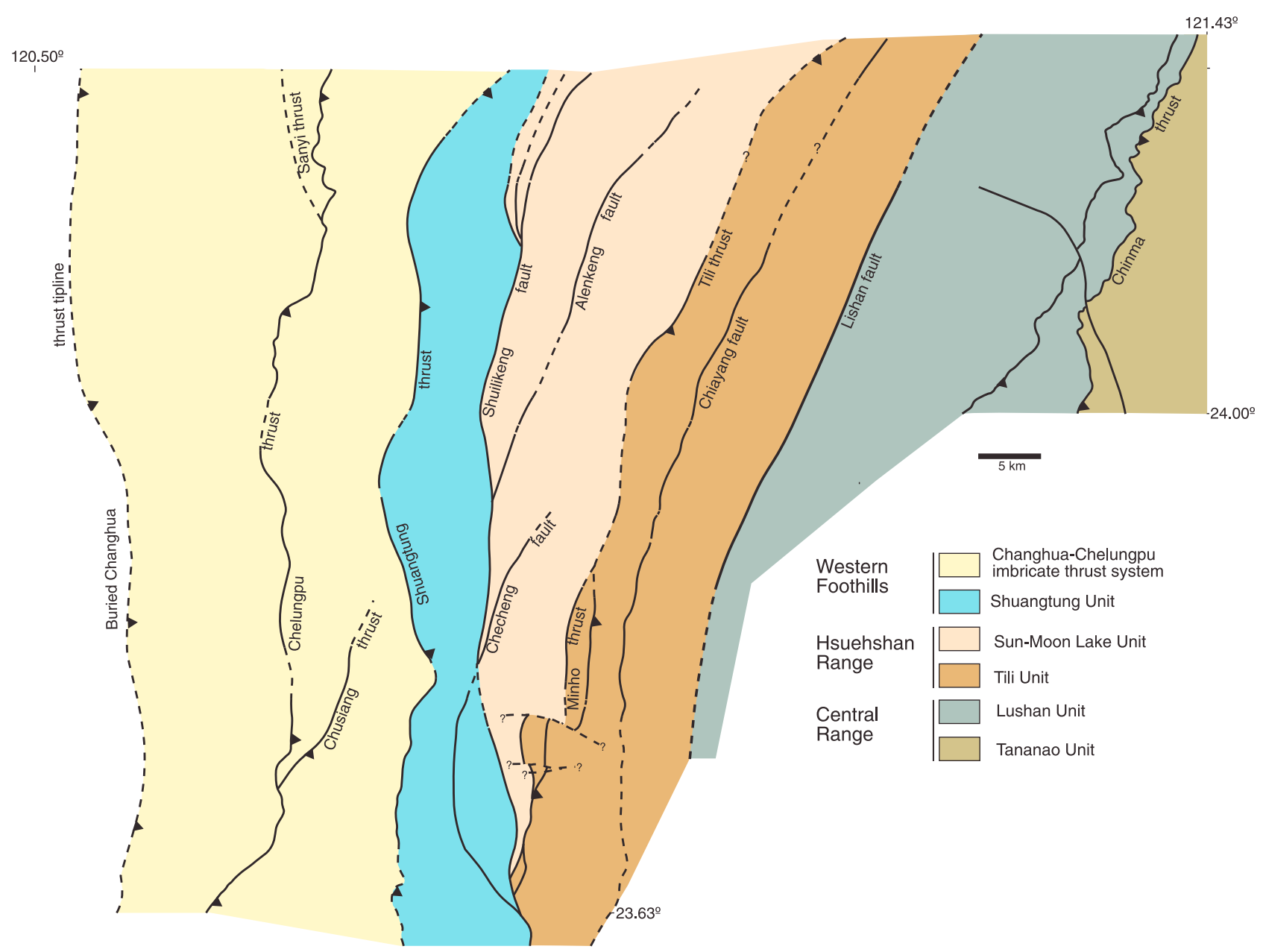

Figure 4. Map of the structural units discussed in the text.

Formation. This contact relationship is clear along, and to the south of, the Choshui River (Figure 2). The lowest part of the Paileng Formation, the Tachien member, has recently been dated by large foraminifera from outcrops along the Choshui River to the south of Wujie (Figure 2) as being late early to early middle Eocene in age [Chen et al., 2009]. The Paileng Formation consists of thick-bedded, coarse-grained to pebble conglomerate quartzite and argillite at its base (the Tachien member), overlain by interbedded sandstone and bioturbated argillite, and topped by a several hundred meter thick, coarsegrained to pebble conglomerate quartzite with minor amounts of lithofragments and feldspar. The total thickness of the Paileng Formation is not known for sure, but it may be as much as 4 to $5 \mathrm{~km}$, and it makes up a large part of the Hsuehshan Range (Figure 2). The Paileng Formation is unconformably overlain by several hundred meters of late early Oligocene interbedded sandstone and shale of the Shuichangliu Formation. Within our map area of the Hsuehshan Range there are no Miocene rocks above the Oligocene, although they do appear farther to the north. There is no evidence, other than in the Puli Basin, that the Pliocene and younger synorogenic sediments were ever deposited on top of the Hsuehshan Range.

[9] The eastern part of the Central Range in the study area is composed of Mesozoic marbles, with lesser lenses of schist (Figures 2 and 3). These Mesozoic rocks are both unconformably overlain by, and in fault contact with, the Pilushan
Formation (Figure 2), which is made up of slate and phyllite with, locally, interbeds of sandstone, all of undifferentiated Eocene age. The Pilushan Formation is thought to have been deposited in a shallow marine environment [e.g., Huang et al., 1997]. Strong folding and penetrative cleavage development, together with difficult access in the high mountains, make it impossible to determine the thickness of the Pilushan Formation. Along its western margin, the Pilushan Formation is in fault contact with the late Oligocene slate, phyllite and metasandstone of the Tayuling Formation (Figure 2), which in turn is overlain by the slate and thin to thick-bedded sandstone of the early to middle Miocene Lushan Formation (Figure 3). Intense folding and cleavage development make it impossible to determine the thickness of these two units. Foraminifera in both the Tayuling and the Lushan Formations suggest that they were deposited in an open marine environment at water depths of between 500 and $1500 \mathrm{~m}$ [Chang, 1976; Huang et al., 1997]. The Lushan Formation is in contact with the rocks of the Hsuehshan Range to the west along the Lishan fault (Figure 2).

\section{Structure}

\subsection{Methodology}

[10] The study area in Central Taiwan (Figure 2: a largerscale version of this map is available in Figure S1 in the 

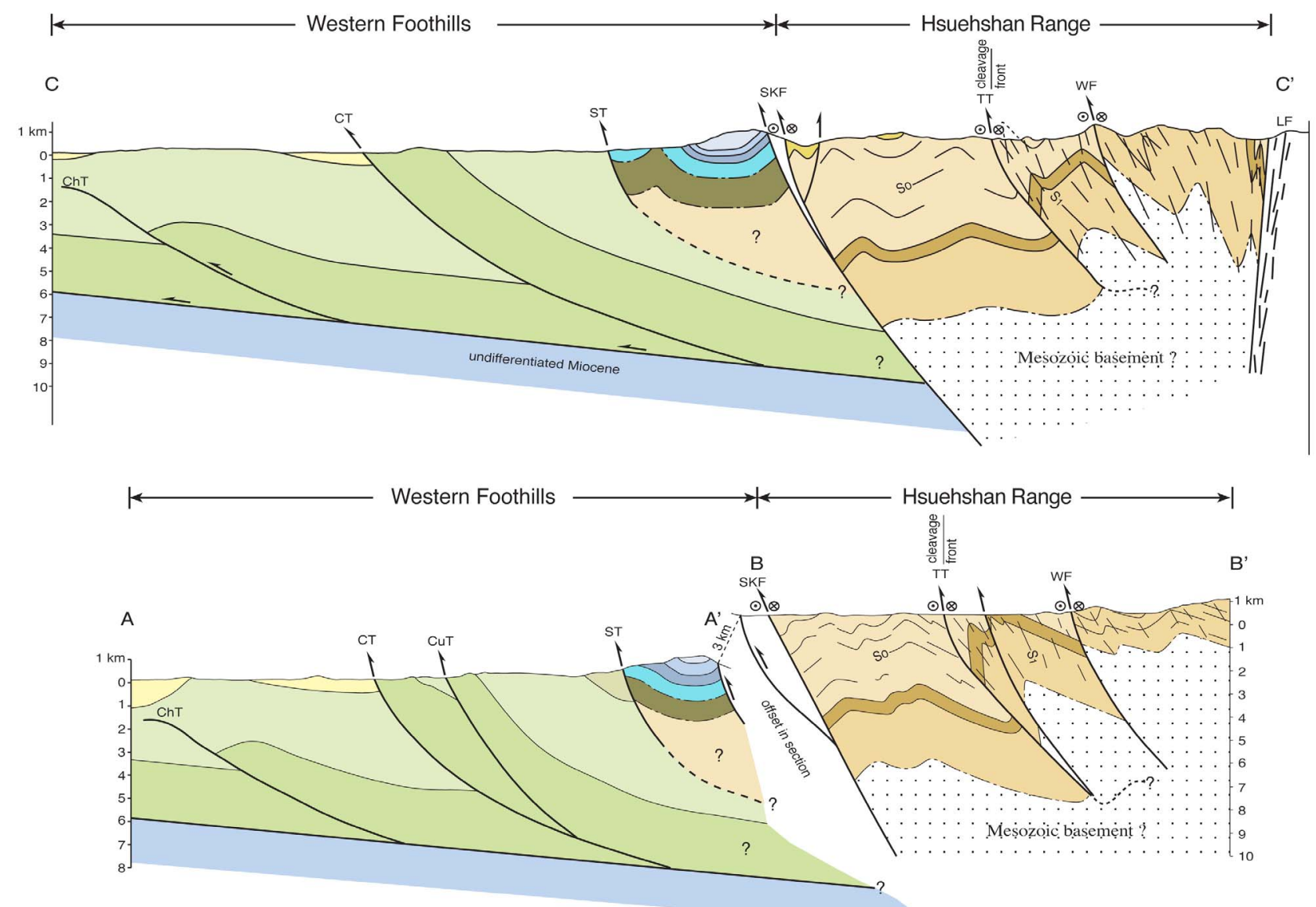

Figure 5. Upper crustal geological cross sections through the central and southern part of the map area. See Figure 2 for the location. $\mathrm{ChT}=$ Chuanghua thrust, $\mathrm{CT}=$ Chelungpu thrust, $\mathrm{CuT}=$ Chusiang thrust, $\mathrm{ST}=$ Shuangtung thrust, $\mathrm{SKF}=$ Shuilikeng fault, $\mathrm{TT}=$ Tili thrust, $\mathrm{CF}=$ Chiayang fault, $\mathrm{LF}=$ Lishan fault.

auxiliary material) covers slightly more than eight 1:50,000 scale topography maps. ${ }^{1}$ Where available, the $1: 50,000$ scale geological maps of the Central Geological Survey were used as base maps, although all of the structural data and the map interpretation presented in Figure 2 are from our own data. There are no data in the north central and southeast parts of the map presented in Figure 2 because of lack of access. In the description of the structure that follows, the map area is divided into a number of individual units that are based on similarities in structure, stratigraphy, and kinematics. From west to east these are; the Changhua-Chelungpu imbricate thrust system, and the Shuangtung, Sun-Moon Lake, Tili, Lushan, and Tananao Units (Figure 4).

[11] Cross sections that are geometrically constrained from the surface geological data are presented for the southern and middle part of the map area in Figure 5. Cross sections for the northern part of the map area are not included for reasons related to the structural complexity found there (see below). The southernmost section is divided into two parts that are offset by $3 \mathrm{~km}$. The cross sections

\footnotetext{
${ }^{1}$ Auxiliary material data sets are available at ftp://ftp.agu.org/apend/tec/ 2012tc003156. Other auxiliary material files are in the HTML. doi:10.1029/ $2012 \mathrm{TC} 003156$
}

were constructed using standard construction techniques [e.g., Dahlstrom, 1969; Hossack, 1979] in which the thicknesses of the formations are taken directly from the surface geological map, and bedding is projected into the subsurface using dip data measured along the section. The location of the basal detachment beneath the Western Foothills is determined using the geometric controls provided by the stratigraphy and the bedding dips, as well as reflection seismic profiles. In other areas, where difficulty in determining the location of a basal detachment where found, we use seismic energy release data to place constraints on the regional interpretation of the deep structure (section 4.2). Because of the often high, rugged topography and dense forest cover, the major faults in the map area are typically poorly exposed along their strike length so satellite images and air photos are used to interpolate their continuity between mapped locations. Below, earthquake focal mechanism data are used to help place further constraints on the kinematics derived from field data. Field geology and seismicity data all indicate that the dominant faults have an overall oblique thrusting through to strike-slip sense of displacement and therefore plane strain cannot be assumed. For this reason we have not provided restored sections, since they would misrepresent the total amount of displacement along most faults. 


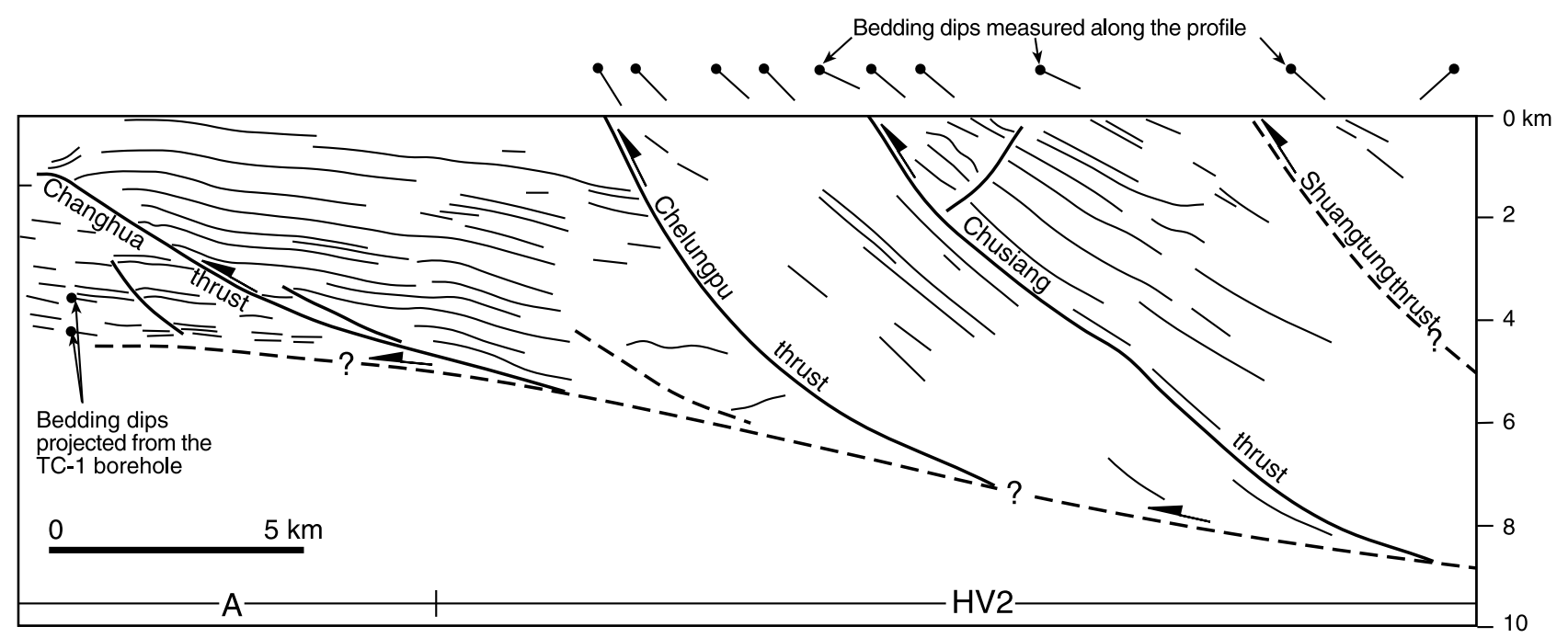

Figure 6. Line drawing of the seismic profiles A (taken from Yue et al. [2005]) and HV2 [Wang et al., 2002]. The locations of these profiles are shown in Figure 2. The seismic profiles are available in Figure S2.

\subsection{The Changhua-Chelungpu Imbricate Thrust System}

[12] The buried Changhua thrust and its associated hanging wall ramp anticlines are developed entirely in the synorogenic Pliocene to Holocene sediments, forming the frontal structure of the mountain belt in central Taiwan (Figures 2 and 5). The structure of this poorly exposed thrust sheet is largely derived from published reflection seismic and borehole data (Figure 6; the uninterpreted data are available in Figure S2) and scarce surface geological data. The reflection seismic data show that the Pakushan anticline has shallow forelimb and back-limb dips that is well imaged in seismic HV2 along the Choshui River [see also Mouthereau et al., 1999; Wang et al., 2003; Yue et al., 2005; Simoes et al., 2007a]. However, farther south, the Neilin anticline plunges moderately $\left(25^{\circ}\right.$ to $\left.30^{\circ}\right)$ northward and locally has a steep to slightly overturned forelimb and moderate back-limb dips (Figure 2).

[13] In the northern part of the map area, the Sanyi thrust (Figure 2), although not exposed here, has been intersected by several boreholes. It is interpreted to splay off the footwall of the Chelungpu thrust, placing Pliocene Kueichulin Formation on top of Holocene gravels [Hung et al., 2009]. The Sanyi thrust outcrops in several places out of our map area. For example, along the Tachia River it affects the Holocene gravels and displays an oblique thrusting, top-tothe-northwest sense of movement [Chen et al., 2003]. The Sanyi thrust sheet widens considerably northward, but this is out of the current study area and therefore will not be considered further here.

[14] To the north of the Choshui River, the Chelungpu thrust sheet is developed in the Pliocene and younger synorogenic sediments. In map view (Figure 2), it juxtaposes the Pliocene Cholan Formation against the Holocene alluvium in the Changhua thrust sheet along the Chelungpu thrust. South of the Choshui River, the Chelungpu thrust ramps down into the Kuechulin and Nanchuang Formations, placing them on top of the Holocene sediments and the
Pleistocene Toukoshan Formation in the back limb of the Neilin anticline (Figure 2). The Chelungpu thrust sheet forms an overall monoclinal structure with bedding $\left(\mathrm{S}_{0}\right)$ that dips shallowly to moderately northeast to southeast (Figures 7 and S3.1), with some scatter caused by local structures. The Chelungpu fault zone outcrops only locally in the map area, so direct observations of its geometry and kinematics are rare. Where it does outcrop, it is a several tens of meters wide zone that ranges in deformation style from highly disrupted and discretely faulted shale to a gouge (see Figure S3.2). While kinematic indicators are largely absent in the Chelungpu fault zone, GPS data [Yu et al., 1997, 2003; Bos et al., 2003; Lin et al., 2010; Ching et al., 2011a], earthquake focal mechanism determinations derived from the 1999 Chi-Chi and other earthquakes [Kao and Chen, 2000; Chang et al., 2000; K. C. Chen et al., 2002; Wu et al., 2008a, 2008b] and, locally, striations on the hanging wall of the 1999 Chi-Chi surface rupture [e.g., Lee and Chan, 2007] indicate that it is an oblique thrust with a top-to-the-northwest sense of movement. In the southern part of the Chelungpu thrust sheet, the Chusiang thrust (Figure S3.3) splays off of the Chelungpu thrust and puts Cholan Formation on top of Toukhshan Formation (Figures 2, 5, and 6). Along the Choshui River there is minor folding in the hanging wall of the Chusiang thrust, but overall bedding dips indicate that it is a monoclinal structure (Figure 2).

[15] Along nearly its entire length in the map area, the Chelungpu thrust is developed in the Chinshui shale, the basal member of the Cholan Formation, suggesting that it is a layer parallel thrust that detaches at this level in the stratigraphy (Figures 2 and 5). However, along the Gan River (Figures 2 and 8), the Chinshui shale is folded into an approximately kilometer wide hanging wall anticline that consists of roughly north and south plunging, box shaped to nearly isoclinal folds (Figure S3.4). In the back limb, bedding has a moderate, consistently eastward dip that projects over the anticline formed by the Chinshui shale. Farther south, along the Cingshuei River, the Nanchuang and 

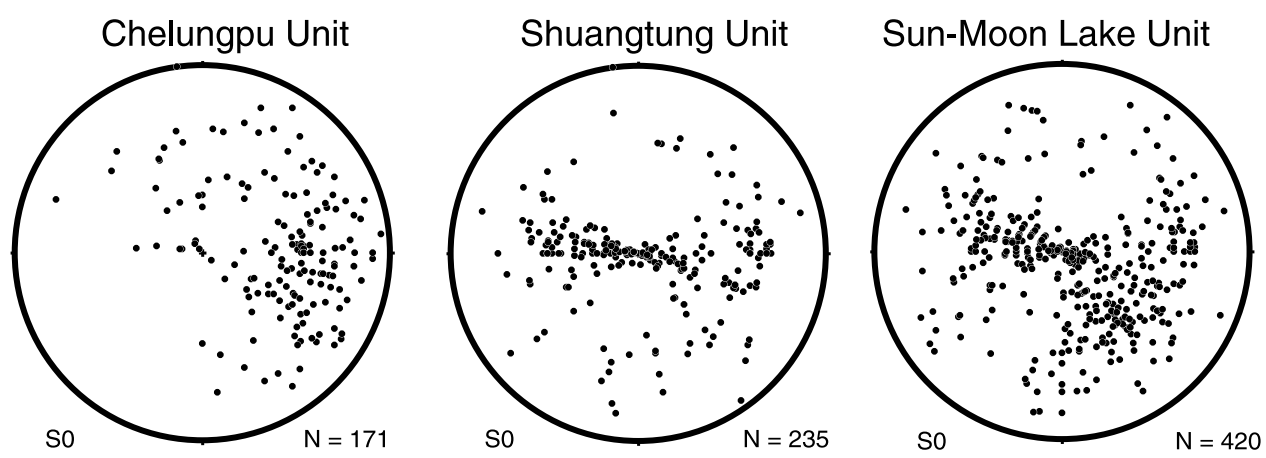

Tili Unit
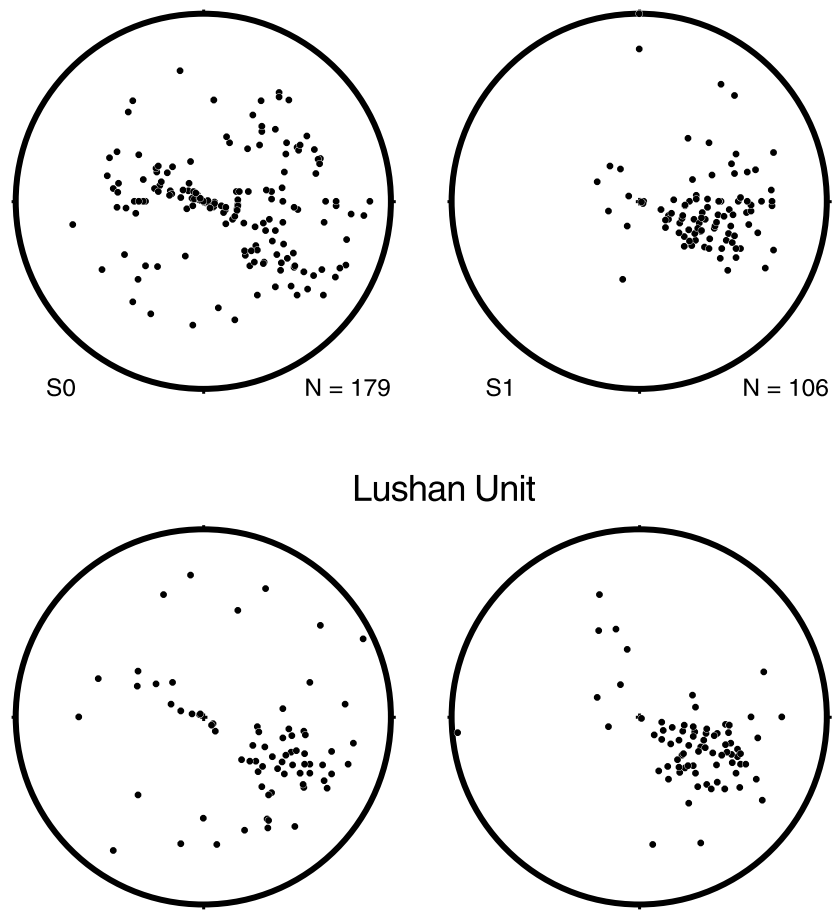

ushan Unit

So

$N=77$

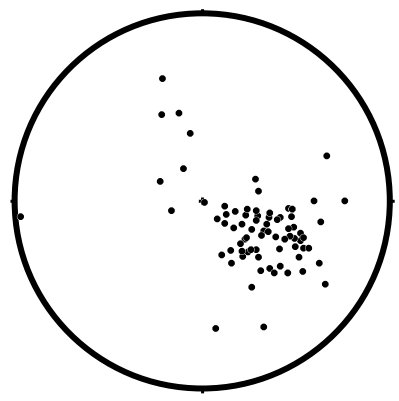

S1

$N=91$

Figure 7. Lower hemisphere, equal-area stereographic projections of bedding and cleavage dip azimuths from the various structural units. These data were plotted using the Stereonet program by R. W. Allmendinger.

Kuechulin Formations are also folded into a series of hanging wall anticlines and synclines immediately above the Chelungpu thrust (Figure 8) (Figure S3.5). While these two areas may provide an opportunity to determine hanging wall cutoffs from which displacement along the Chelungpu thrust can be determined, we hesitate to do so on the basis of these two outcrops alone.

[16] Based on bedding dips and the reflection seismic data, the Changhua and Chelungpu thrusts can be interpreted to be listric faults that merge with a basal detachment that dips $\sim 6^{\circ}$ eastward, forming an imbricate thrust system (Figures 5 and 6). The dip of the detachment is consistent with the footwall bedding dips below the Changhua thrust obtained from the borehole TC-1 (Figure 6), with the interpretation of reflection seismic data, and is in keeping with the dip interpreted by other studies [e.g., Johnson and Segall, 2004; Mouthereau and Lacombe, 2006; Simoes et al., 2007a; Lee and Chan, 2007]. Hanging wall bedding dips are moderate along the area of the cross sections, and by maintaining formation thicknesses we interpret the Changhua and Chelungpu thrusts to merge with the basal detachment at $\sim 6$ and between 8 and $9 \mathrm{~km}$ depth, respectively (Figures 5 and 6). This interpretation places the location of the 1999 Chi-Chi earthquake [Wu et al., 2008a, 2008b] on the Chelungpu thrust, near where it merges with the basal detachment. It also fits well with the hypocenter locations of seismic events within the first $15 \mathrm{~min}$ of the Chi-Chi aftershock sequence [Chang et al., 2007]. Other interpretations have the Chelungpu thrust splaying off the basal detachment at $\sim 4$ to $10 \mathrm{~km}$ depth, or even more [Kao and Chen, 2000; Chen et al., 2001b; Johnson and Segall, 2004; Yue et al., 2005; Mouthereau and Lacombe, 2006; Mouthereau et al., 2001; Lin, 2007; Lee and Chan, 2007; Huang et al., 2008; Yanites et al., 2010]. Based on the 


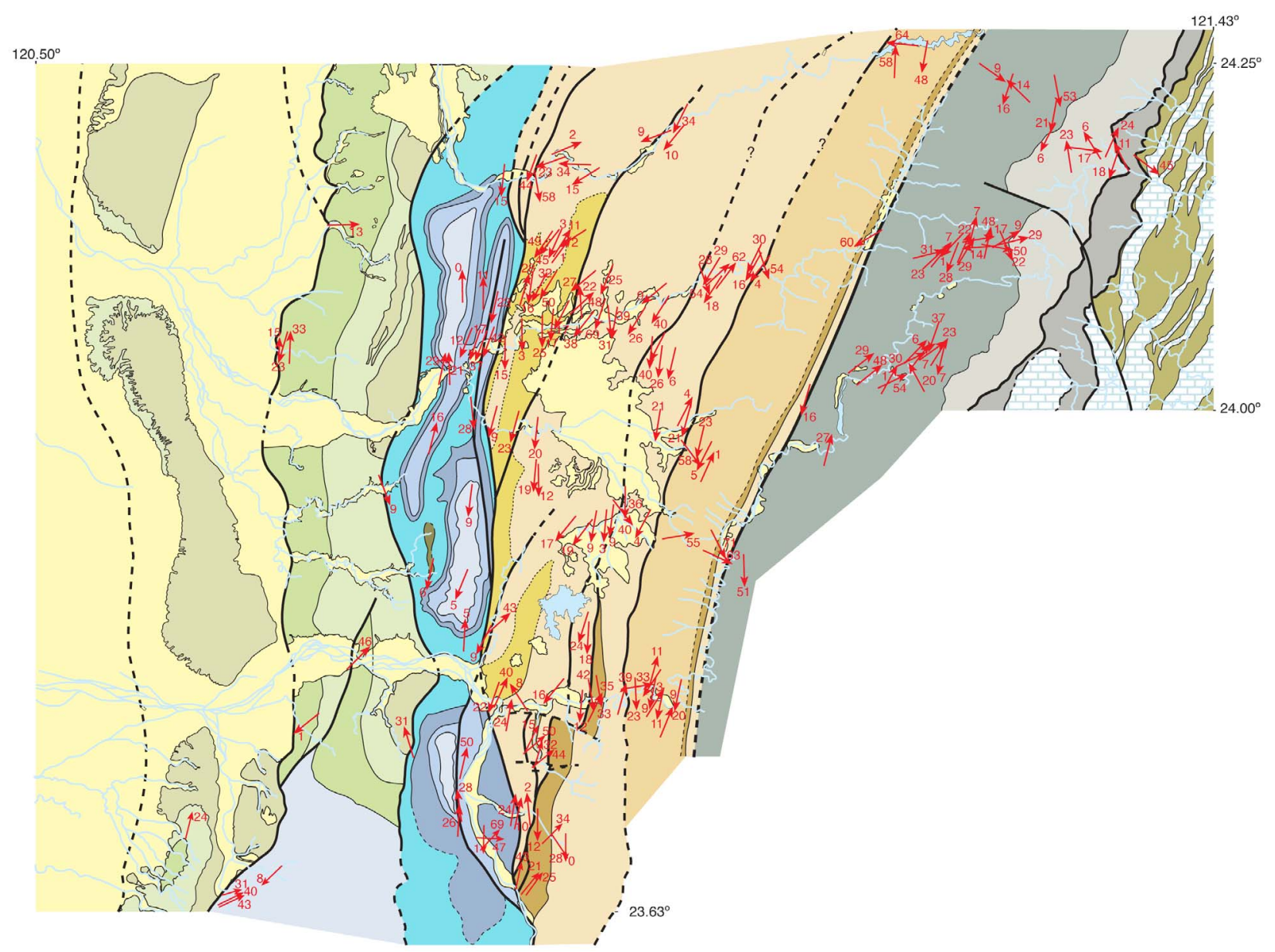

Figure 8. Map of fold axes orientations and plunge values throughout the study area. To the north of the Choshui River, fold axes plunge overall toward the south, whereas south of the river they take on a northward plunge.

disruption of seismic reflections, horizontal displacement on the Changhua thrust in the plane of the seismic profile appears to be on the order of $500 \mathrm{~m}$ [see also Yue et al., 2005; Mouthereau and Lacombe, 2006; Simoes et al., 2007a]. In our cross sections, the apparent displacement along the Chelungpu thrust is a minimum of $\sim 15 \mathrm{~km}$ if the intersection of the Cholan Formation with the surface is restored to its footwall cutoff. We stress, however, that movement of material out of the plane of section by oblique thrusting, together with the scarcity of stratigraphic cutoffs, make it difficult to accurately determine the amount of displacement for the Chelungpu thrust sheet. Finally, the fact that to the south of the Choshui River the Chelungpu thrust cuts down section in the stratigraphy (Figure 2) indicates the presence of a lateral, or oblique, ramp that appears to strike roughly NE-SW.

\subsection{The Shuangtung Unit}

[17] In map view, the Shuangtung Unit comprises middle to late Eocene through to early Pliocene rocks which are juxtaposed against the late Miocene to Pleistocene rocks of the Chelungpu Unit along the Shuangtung thrust in the west, and in the east against the Eocene and Oligocene rocks of the Sun-Moon Lake and Tili Units along the Shuilikeng fault (see section 3.4) (Figure 2). The involvement of the older platform margin strata in the deformation indicates that the Shuangtung thrust ramps down into a deeper stratigraphic level than the basal detachment of the Changhua-Chelungpu imbricate thrust system.

[18] The Shuangtung thrust outcrops very poorly in the field and kinematic indicators are largely lacking. Coseismic and postseismic horizontal GPS velocities associated with the 1999 Chi-Chi earthquake indicate that it is an oblique thrust with a top-to-the-northwest sense of movement [Yu et al., 2003; Lin et al., 2010]. Along the Changping River (Figure 2), the fault is expressed as a narrow zone of gouge with a decameter-scale west verging hanging wall anticlinefootwall syncline pair (Figure S3.6). Along the Wu River, a number of small faults indicate a top-to-the-northwest sense of movement. In the northern part of the map area, the Shuangtung thrust takes on a northeast strike, as do bedding traces in its hanging wall. The Shuangtung thrust has been poorly imaged in reflection seismic profiling (Figure 6), where it appears to be a moderately to steeply eastward dipping fault [see also Wang et al., 2003; Yue et al., 2005; Simoes et al., 2007a, 2007b].

[19] The surface geology of the Shuangtung Unit comprises two wide "en echelon" synclines, the Tahenpingshan 
and Taanshan synclines in the north and south, respectively (Figure 2). Note that here we interpret the Taanshan and Chichitashan synclines [C.-S. Huang et al., 2000] to be the same structure. These synclines are separated by the narrow Tsukeng anticline that is cored in its southern part by the Eocene age Tsukeng Formation. These folds are noncylindrical (Figure 8), as is shown by the weak great circle girdle formed by bedding dips within the unit (Figure 7), and are cut by both the Shuangtung thrust and the Shulilikeng fault.

[20] In the northern part of the map area, the eastern flank of the Shuangtung Unit is tightly folded (Figures S3.7 and S3.8 show vertical bedding along this limb) into the moderately southward plunging Guaosing anticline (Figure S3.9) and Tachiwei syncline (Figure 2). The eastern limb of the Tachiwei syncline and the eastern flank of the Taanshan syncline are cut by the high-angle, brittle Guaosing fault (Figures S3.10 and S3.11), which merges southward with the Shuilikeng fault. No kinematic indicators have been found along the Guaosing fault. Southward, the eastern limb of the Taanshan syncline becomes steeply west dipping and is cut by high-angle brittle faults. Several of these faults are well exposed along the western side of the Chenyulan River where they can be up to several hundred meters wide breccia zones that strike into and become lost in the alluvium of the river valley. In several locations we have found psuedotachylite within the breccia. Kinematic indicators such as stratigraphic cutoffs and slickenfibers developed on slip surfaces show that the faults have a complex kinematic history, but with a dominant sinistral strike-slip sense of movement.

[21] In both cross sections, the Shuangtung thrust juxtaposes a hanging wall ramp against a footwall ramp (Figure 5). We have little control on the dip or location of the Shuangtung thrust at depth, except that it carries Eocene age rocks in its hanging wall [Chiu, 1975; C-Y. Huang, personal communication, 2012]. There are, then, two possibilities for the interpretation of the structural provenance of the Shuangtung Unit. In the first, the Shaungtung thrust forms a ramp up from a deeper stratigraphic level than the Changhua-Chelungpu imbricate thrust system to form the bedding-parallel flat beneath it (the detachment). In this case, the Shuangtung Unit forms part of the imbricate system and must, therefore, restore back to a position farther east than that of the synorogenic sediments in the Chelungpu thrust sheet, indicating that it has accumulated a horizontal displacement of more than $15 \mathrm{~km}$ and has been uplifted more than $12 \mathrm{~km}$ (if a $6^{\circ}$ basal detachment dip is assumed) [see, e.g., Yue et al., 2005]. A second possibility is that the Shuangtung thrust is linked to the development of the Shuilikeng fault (see below) and represents a footwall shortcut breaching through the Changhua-Chelungpu imbricate thrust system and may involve both basement and cover rocks [see also Mouthereau and Lacombe, 2006; Simoes et al., 2007b]. In this scenario (which we prefer), the Shuangtung Unit has accumulated $\sim 10 \mathrm{~km}$ of horizontal displacement and has been uplifted $\sim 9 \mathrm{~km}$. Continued movement along the Shuilikeng fault has resulted in the eastern margin of the Shuangtung Unit being tightly folded and faulted. In this latter case, any synorogenic sediments that may have been deposited above the Miocene in the Shuangtung Unit in the map area have now been eroded away, although they do appear above the Miocene in the Changhua-Chelungpu imbricate thrust system farther to the south (Figure 2).

\subsection{The Sun-Moon Lake Unit}

[22] The Sun-Moon Lake Unit is composed of Eocene and Oligocene sediments of the Paileng and the Shuichangliu Formations (Figure 2) and represents a yet deeper level of involvement of the Eurasian margin sediments in the deformation. A deeper level of burial for these rocks has been suggested by Sakaguchi et al. [2007], who, on the basis of vitrinite reflection data, determined an increase in temperature of $90^{\circ} \mathrm{C}$ from the Shuangtung Unit to Sun-Moon Lake Unit, across the Shuilikeng fault. They estimate a maximum temperature of $284^{\circ} \mathrm{C}$ for the Paileng Formation, and suggest that the Sun-Moon Lake Unit rocks have been exhumed from between 9.2 and $9.8 \mathrm{~km}$ depth. The Sun-Moon Lake Unit is bound to the west by the Shuilikeng fault and to the east by the Tili thrust.

[23] The Shuilikeng fault is a high-angle (Figures S3.12 to S3.14), roughly linear, locally bifurcating brittle fault zone that coincides with a pronounced system of valleys that clearly demarcate the contact between the Shuangtung and the Sun-Moon Lake and Tili Units along nearly its entire length in Central Taiwan (Figure 2). Using river incision, channel morphology, and stream gradients along the $\mathrm{Wu}$ and Peikang rivers, Yanites et al. [2010] and Sung et al. [2000] suggest that the Shuilikeng fault is currently active, and has been throughout the Holocene. Furthermore, by comparing today's stream gradients with historical gradients from earlier mapping, Sung et al. [2000] suggest that the Shuilikeng fault has been active during the last 80 years. The Shuilikeng fault is poorly imaged in reflection seismic data, where it has been interpreted to dip steeply eastward and extend to deep in the middle crust (i.e., the Shuichangliu fault of Wang et al. [2002]). Yue et al. [2005] interpret the Shuilikeng fault to be the westward dipping displaced upper part of a preexisting extensional fault whose lower part, they suggest, coincides with an area of high seismic activity below their interpreted detachment.

[24] The surface geology of the Sun-Moon Lake Unit is defined by a number of roughly NE striking regional-scale folds and faults that splay off the Shuilikeng fault zone. Faults are often difficult to trace along strike, but where they crop out they are all brittle with mostly a top-to-thenorthwest sense of movement. Here, unlike previous map interpretations, we recognize a fault along the eastern flank of the Lileng syncline, which we name the Alenkeng fault (Figure 2). While this fault has not been seen in outcrop, its presence is inferred from complex, nearly vertically plunging folds along the eastern margin of the syncline to the north of the Paikang River, and by the truncation of gently east dipping Shuichangliu Formation against vertical, west facing Paileng Formation on the north side of the Nankhan River (Figure 2). The regional anticlines associated with the major faults in the Sun-Moon Lake Unit have moderately to steeply west to northwest dipping forelimbs (Figures S3.15 and 3.16) that, northward, become steep to slightly overturned as folds tighten (Figure 2). These steep forelimbs can often be traced for tens of kilometers along strike, making them excellent structural markers in the rugged topography and monotonous stratigraphy of the Paileng Formation. 
Folds have a broad back limb with bedding that dips shallowly to moderately toward the northeast to southwest, giving the synclines an open to slightly flat-bottomed geometry (Figure S3.17 and Figures S3.18 to S3.20 show further details of the stratigraphy and structure in the SunMoon Lake Unit). The folds are everywhere fault propagation folds, generally with a component of bedding parallel slip. Throughout most of the Sun-Moon Lake Unit, minor folds associated with the regional fold system have axes that (with some exceptions) plunge shallowly to moderately southward, but take on a more southwesterly plunge north of the Peikang River, and turn sharply to a nearly east-west plunge along the Tachia River, giving a scatter in the bedding dip azimuths (Figures 7 and 8). South of the Choshui River, fold axes have an overall northward plunge (Figure 8).

[25] In cross section, we have assumed a stratigraphic thickness template for the Sun-Moon Lake Unit as outlined in section 2. We interpret the Mesozoic basement to be in the shallow subsurface on the basis of the velocity structure determined from seismic tomography [Wu et al., 2007; Lin, 2007]. The regional-scale structure of the Sun-Moon Lake Unit in the southern part of the map area is that of a hanging wall ramp composed of a wide antiformal structure with a number of associated minor folds. On the basis of the surface geology, in the cross sections we interpret the Shuilikeng fault to be a steeply east dipping feature that extends to $\sim 10 \mathrm{~km}$ depth where it ramps down to a deeper level than the Western Foothills basal detachment (Figure 5). Below, we will use seismicity data to interpret how the Shuilikeng fault extends deeper into the crust and to place constraints on its kinematics. Further north, between the Peikang and the Tachia rivers, faults, regional bedding strikes, and fold axes undergo a pronounced change in orientation toward a more northeast to easterly strike and plunge (Figures 2, 7, and 8). This change in the structural orientation is suggestive of a roughly NE-SW striking lateral, or oblique, footwall ramp.

\subsection{The Tili Unit}

[26] The surface geology of the Tili Unit is composed of the Chiayang and Shipachungchi Formations, and the lower (Tachien) and middle members of the Paileng Formation. Much of the northeastern part of the Tili Unit is difficult to access, so we have only a relatively small data set from there. The Tili Unit is bound to the west by the Tili thrust and to the east by the Lishan fault. The Tili thrust marks an abrupt change in the deformation style and metamorphic conditions in the Taiwan mountain belt. It is the western limit of cleavage development. South of the Choshui River, the Tili Unit appears to be offset to the west before it bends into, and terminates against, the Shuilikeng fault (Figure 2). On the basis of Raman spectroscopy of carbonaceous material, Beyssac et al. [2007] estimate metamorphic temperatures in the Tili Unit to range from $\sim 350^{\circ} \mathrm{C}$ to greater than $450^{\circ} \mathrm{C}$, significantly higher than the $284^{\circ} \mathrm{C}$ determined for the Sun-Moon Lake Unit [Sakaguchi et al., 2007] [see also Simoes et al., 2012].

[27] Where it outcrops, the Tili thrust is a wide zone of deformation in which numerous small faults interact with each other (see Figure 3.21 for an example of the complex deformation around the Tili thrust). The largest of these splays occurs in the southern part of the map area, where the Minho thrust splays off the Tili thrust to form a several tens of kilometers long horse. South of the Choshui River, the Minho and Tili thrusts are offset some 5 to $10 \mathrm{~km}$ to the west. A number of east-west striking, both northward and southward dipping thrust and strike-slip faults outcrop in this area. Although it is not possible to trace any one of these faults in outcrop through the forest and high topography, using satellite imagery we interpret the offset in the Tili Unit to be related to them. The Tili Unit contains a moderate to steeply east to east-southeast dipping (Figure 7) pressure solution cleavage that is axial planar to minor asymmetric, west vergent folds found in outcrop (Figure S3.22), and to the regional fold structure [see also Clark et al., 1993; Tillman and Byrne, 1995; Fisher et al., 2002]. There is some local scatter in the dip directions of the cleavage, especially in the northern and southern parts of the map area where they are affected by the Lishan and Shuilikeng faults, respectively.

[28] The regional structure of the Tili Unit is that of the west verging, moderately southward plunging Tanan anticline (Figures 2 and 5), which has a several kilometer wide, steep to slightly overturned forelimb and a wide (Figure S3.23), moderately eastward dipping back limb (Figures 2 and 5). The geometry of the Tanan anticline is that of a fault propagation fold (see Figure S3.24 for an example of the fold style). As in the Sun-Moon Lake Unit, bedding dip directions (and here cleavage) take on a complex pattern in the northern part of the map area (Figure 2) (see also Tillman and Byrne [1995] for details of cleavage orientations in the northern part of the Tili Unit). The back limb of the Tanan anticline is cut by the Chiayang fault (Figure S3.25), which juxtaposes Chiayang Formation against the Tachien member of the Paileng Formation (Figure 2). The Chiayang fault can be traced throughout the map area as a several hundred meter wide zone of brittle deformation. Sparse kinematic indicators found in outcrops along the Choshui, Paikang and Tachia rivers suggest that this is a highly oblique thrust to strike-slip fault. North of the Choshui River, minor folds in the Tili Unit have an overall shallow southward plunge, although this can be highly complex where, locally, folds become reclined (i.e., the fold axis plunges downdip in the axial plane) (Figure 7). South of the Choshui River, minor folds in the Tili Unit generally plunge toward the north. Along its eastern flank, the lower part of the Paileng Formation in the back limb of the Tanan anticline has been rotated into a vertical position against the Lishan fault (Figures 2, 5, and S3.26).

[29] In the cross sections, the Tili thrust is interpreted to be a relatively steeply dipping fault that penetrates into the Mesozoic basement, juxtaposing a hanging wall ramp against a footwall ramp (Figure 5). This interpretation is based on the fact that along its strike length in the map area the Tili thrust cuts across the topography from the northeast to the southwest, suggesting that it is a steeply dipping feature. An alternative interpretation is that it shallows into a detachment within the complexly and strongly folded Chiayang Formation, and/or at the interface with the basement. We stress, though, that there is no geological evidence to support either of these interpretations. Finally, with the current data set it is not possible to determine if back rotation and steepening of the Tili thrust has taken place with the progressive development of the fault units to the west. 
[30] Eastward, the Tili Unit is bound by the Lishan fault, a north to northeast striking high-angle fault that has a marked topographic expression throughout much of central and northern Taiwan. In several interpretations of the geology of Taiwan the Lishan fault has been largely ignored [e.g., C.-H. Chen et al., 2000; Yue et al., 2005]. Others have suggested, however, that the Lishan fault is a geologically complex, steeply west dipping structure whose geophysical signature indicates that it can be traced into the middle and perhaps even the lower crust and that it has an overall top-to-the-east oblique thrusting to strike-slip faulting sense of movement [Clark et al., 1993; Lee et al., 1997; Bos et al., 2003; Wu et al., 2004; Bertrand et al., 2009, 2012]. Neither of these interpretations has been supported by a clearly defined fault surface in the field. In our map area, however, the Lishan fault outcrops in a number of places, where it is an up to $1 \mathrm{~km}$ wide ductile shear zone (Figures S3.27-S3.29) that juxtaposes the early to middle Eocene [Chen et al., 2009] lower members of the Paileng Formation to the west against the middle Miocene Lushan Formation to the east. In the upper reaches of the Choshui River, near the town of Wujie, the fault is very well exposed. Here, it is a several hundred meter wide shear zone that displays a strong strain gradient from lower strain at the margins to very high strain at its center. Kinematic indicators, such as sheared boundins, sheared lithoclasts, and rare subhorizontal lineations indicate a sinistral sense of strike-slip movement. Furthermore, the Lishan fault has medium metamorphic grade rocks being exhumed in its hanging wall (up to $\sim 450^{\circ} \mathrm{C}$ [Beyssac et al., 2007; Simoes et al., 2012]). All of these features combine to suggest that the Lishan fault penetrates to below the brittle ductile transition (since ductilely deformed rocks now appear at the surface), and into rocks that were at middle to lower crustal metamorphic conditions.

\subsection{The Lushan Unit}

[31] The Lushan Unit is composed of the deep water shales and sandstones of the middle Miocene Tayuling and Lushan Formations, and here we also include the Eocene Pilushan Formation. The difference in age and depth of deposition between the Pilushan Formation and the Tayuling Formation (see section 2.2) is suggestive of either an unconformity or a structural break. The complexity of the structure across the contact supports the interpretation of a fault, although no clearly defined fault was seen in our map area. The Lushan Unit is bound to the west by the Lishan fault and to the east by the Chinma fault. Despite its poor exposure, we have mapped several sections along its western flank and one complete section in the north (Figure 2). However, the poor exposure combined with the monotonous lithology does not provide any marker horizon that allows correlation of structures to be made from north to south. This is further complicated by the gradual southward disappearance of bedding in the Lushan Formation. Metamorphic temperatures in the Lushan Unit are estimated to be $<300^{\circ} \mathrm{C}$, significantly less than that determined from the Tili Unit to the west [Beyssac et al., 2007; Simoes et al., 2012].

[32] Folds in the Lushan Unit have a wavelength of several hundred meters to a kilometer, are roughly west verging (Figure 2), and generally northeast to southwest plunging (Figure 7). They have steep to overturned forelimbs and moderately dipping back limbs. Locally, however, minor folds are very tight, with interlimb angles on the order of $10^{\circ}$ to $30^{\circ}$. These folds often plunge downdip in their axial plane. A spaced axial planar cleavage is developed throughout the unit (but not always in the thick-bedded sandstones) (Figure S3.30) and has an overall moderate southeast dip (Figure 6), although dip directions become more variable northward (Figure 2). We have observed a crenulation cleavage in only one outcrop, indicating that a second phase of folding is not widespread in the Lushan Unit. Zones of very high strain are found locally along its western flank. For example, near the western side of the town of Lushan (Figure 2), one shear zone is several hundred meters wide, contains abundant lithoclasts with symmetrical strain shadows (Figure S3.31), rootless folds, and widely spaced kink bands (Figure S3.32). Unfortunately, these high-strain zones cannot be traced away from the outcrop in which they occur, and their kinematics are typically ambiguous. The western margin of the Lushan Unit is strongly deformed by the Lishan fault.

\subsection{The Tananao Unit}

[33] The Mesozoic rocks of the Tananao Unit have been interpreted to be either unconformably overlain by the Pulishan Formation [Suppe, 1976; Yue et al., 2005] or to be in fault contact with it [Clark et al., 1993; Fisher et al., 2002; Gourley et al., 2007; Beyssac et al., 2007]. The contact between these two units is exposed along the Central Cross Island Highway, at the Chinma tunnel (Figure S3.33). Here, the banded marbles that are typical of the Tananao Unit in the Taroko Gorge (Figure S3.34) are overprinted by a penetratively developed mylonititic foliation that dips $\sim 60^{\circ}$ toward the east (Figure S3.35). Our current mapping only extends $2 \mathrm{~km}$ east of this contact, so in this paper we will not address the geology of the Mesozoic rocks of the Tananao Unit.

\section{Earthquake Data}

[34] In sections 4.1 and 4.2, focal mechanism type maps and seismic energy release depth slices and cross sections are presented for earthquake data within the map area. Key to the interpretation of these data is the accuracy of the hypocenter location and of the focal mechanism solution [Wu et al., 2008a, 2008b]. Precise earthquake locations rely on several factors such as record quality, station coverage, the adopted methodology of relocation, and the velocity model. The Central Weather Bureau Seismic Network (CWBSN) and Taiwan Strong Motion Instrumentation Program (TSMIP) stations consist of about 900 free-field stations spread over the entire Taiwan mountain belt, with a dense array of these within the study region. Events recorded in both the CWBSN and TSMIP data sets were relocated using the 3-D velocity model of $W u$ et al. [2007, 2009]. By using the 3-D velocity model and dense station coverage, the root-mean-squares of the traveltime residuals are shortened to less than $0.15 \mathrm{~s}$ [Wu et al., 2003, 2008a]. This, together with results from recent test explosions, gives an uncertainty of $\pm 2 \mathrm{~km}$ in hypocenter locations. First motion polarities from 834 of the relocated events within the study area were suitable for focal mechanism determinations, which are calculated using the genetic algorithm [Wu et al., 2008b] to explore the entire model space and to assess the robustness 


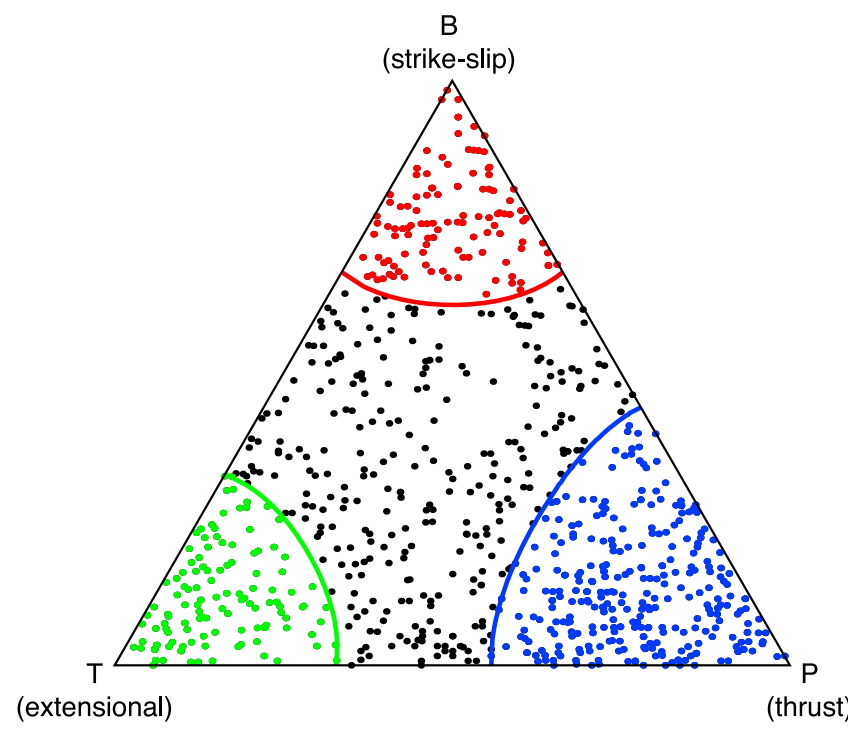

Figure 9. Triangular plot showing the fault mechanism distribution for the study area [after Frohlich, 2001]. These data are available in Data Set $\mathrm{S} 1$.

of solutions. A complete description of the methodology and the uncertainties involved in the calculation of the focal mechanisms is given by $W u$ et al. [2008b].

[35] While small, we stress that the scale of these uncertainties in the location of individual seismic events and focal mechanisms, together with uncertainties in determining the exact subsurface location of faults from surface geology, make it difficult to assign any particular seismic event to the smaller faults in the map area. It is, however, possible to distinguish a number of the major bounding faults. Because of the scale of the analyses and the uncertainties involved, this data set provides further constraints on the regional interpretation of the structure and kinematics derived from the surface geology. Therefore, in this section, we return to the regional tectonostratigraphic terminology of Western Foothills, Hsuehshan Range, and Central Range.

\subsection{Focal Mechanism Data}

\subsubsection{Methodology}

[36] Focal mechanism data are updated from the database of $W u$ et al. [2010] to cover the period from 1991 to 2009 (Data Set S1). Focal mechanism solutions from this data set were used to determine the P, T, and B axes of each event, which were then plotted according to the method of Frohlich [1992, 2001] (Figure 9). Although information such as the incremental slip direction and fault plane strike are lost in this analysis, the focal mechanism types provide important information on fault kinematics, dividing the seismic events loosely into fields that define thrusts ( $\mathrm{P}$ axis), extensional faults (T axis), strike-slip faults (B axis), and "other" faults. Once the focal mechanism types were characterized in this way they were plotted in situ in the same volume used for the energy release analysis (see section 4.2) and depth slices were cut at $5 \mathrm{~km}$ intervals (Figure 10). For the depth slices, events were projected vertically for a maximum of $2.49 \mathrm{~km}$ either side of the slice, assuring that no single event appears on two different slices.

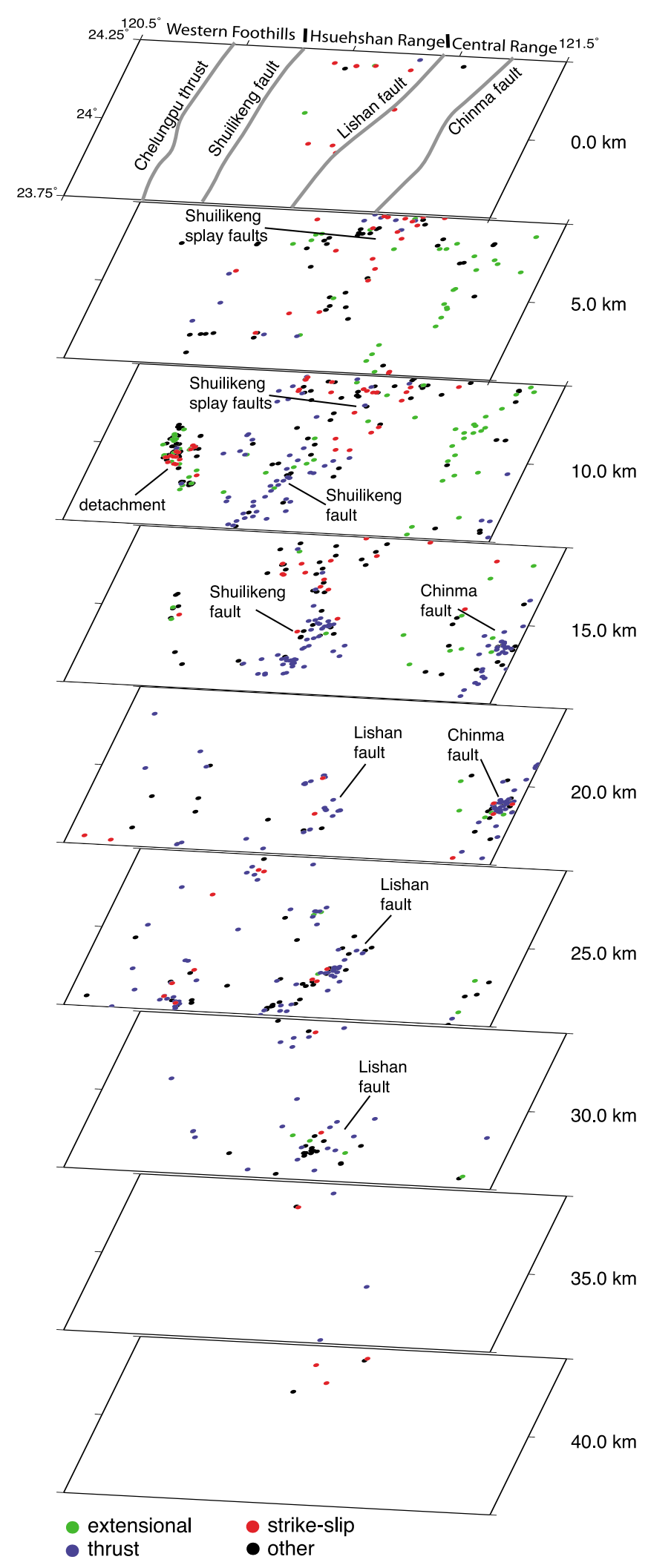

Figure 10. Fault mechanism depth slices through the map area. See text for discussion. 

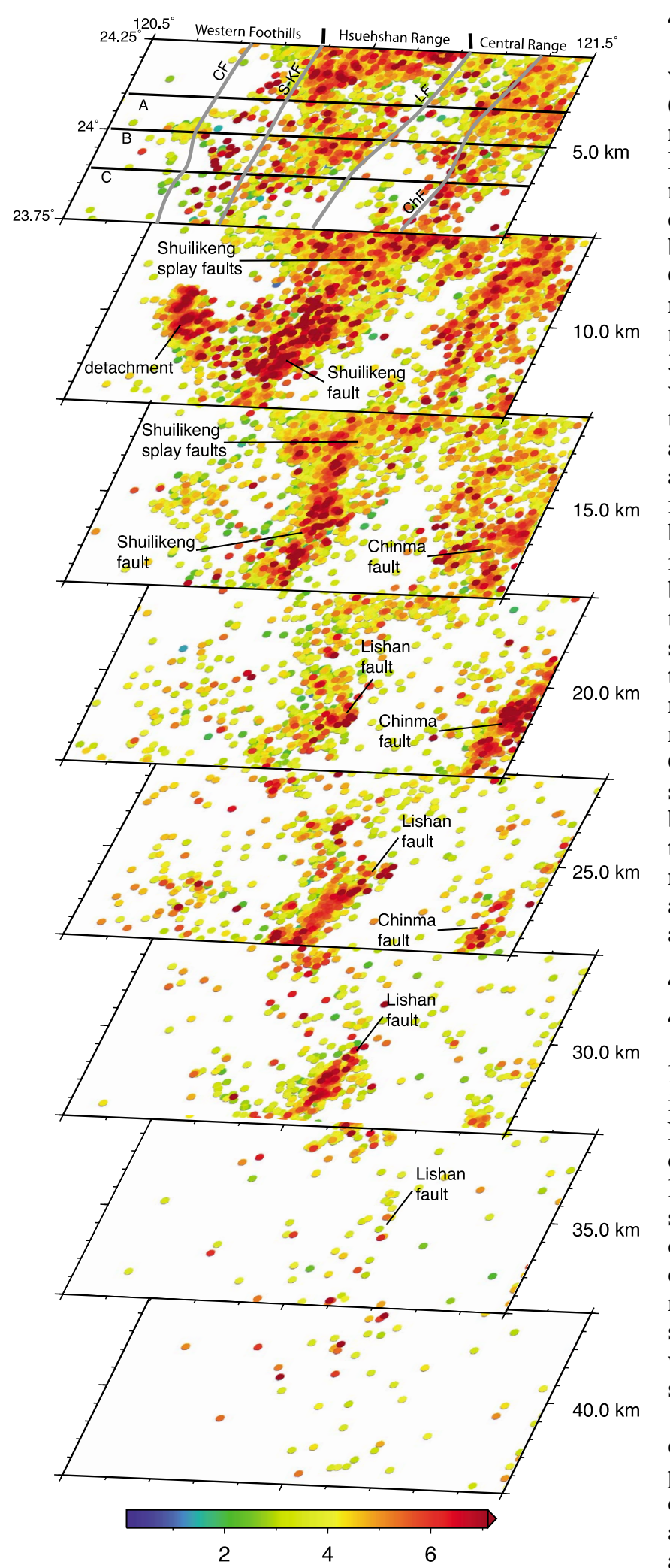

Log of Cumulative Energy (ergs)

Figure 11. Seismic energy release depth slices for the study area. Note the coincidence of the linear highs which are interpreted to be related to the basal detachment, the Shuilikeng and Lishan faults. The data set from which these energy releases were calculated is available in Data Set S2.

\subsubsection{Fault Mechanisms in Central Taiwan}

[37] Figure 9 displays an overall random scatter, with a weak clustering in the thrust field. The depth slices (Figure 10), however, show a complex distribution of fault mechanisms, both within a single depth slice and with depth. In the Western Foothills, the upper $15 \mathrm{~km}$ of crust is dominated by strike-slip, extensional, and "other" faults, with a cluster of these centered at $\sim 10 \mathrm{~km}$ depth that we interpret to be related to the basal detachment beneath the ChanghuaChelungpu imbricate thrust system. Thrust mechanisms are rare in the upper $15 \mathrm{~km}$ of the Western Foothills, but become more important, along with "other" types, from $\sim 15$ to $30 \mathrm{~km}$ depth. Eastward, the Hsuehshan Range displays a very complex pattern of fault types. In the northern part of the map area, the upper $15 \mathrm{~km}$ is dominated by strike-slip and "other" fault mechanisms, with a minor number of thrust and extensional events that are interpreted to belong to the faults that splay off the Shuilikeng fault. In the south, beginning at $\sim 10 \mathrm{~km}$ depth, the Hsuehshan Range is dominated by a near linear cluster of thrusts that extend to between 15 and $20 \mathrm{~km}$ depth that we interpret to be related to the Shuilikeng fault. Between $\sim 20$ to $30 \mathrm{~km}$ depth, the southeastern flank of the Hsuehshan Range is dominated by thrust and "other" mechanisms, with lesser strike-slip and rare extensional mechanisms that are interpreted to be related to the Lishan fault. The upper $10 \mathrm{~km}$ of the part of the Central Range covered in this study is dominated by extensional fault mechanisms, with thrust fault mechanisms becoming increasingly important in the southeastern part of the map, from $\sim 15$ to $25 \mathrm{~km}$ depth. We interpret these to be related to the Chinma fault. Similar results to those outlined above were obtained in central Taiwan by $W u$ et al. [2010] and Mouthereau et al. [2009].

\subsection{Seismic Energy Release Data}

\subsubsection{Methodology}

[38] Earthquake hypocenter maps and sections with a large number of seismic events can provide important information about the regional geometry of fault systems. Nevertheless, there are several disadvantages to this methodology. For example, clustering of events may be misleading in the visual inspection of maps and sections, since small-magnitude events cannot be distinguished from large ones. With an energy increase of about a factor of 30 for each unit increase in magnitude, the cumulative energy released by many small events may not reach the energy of a single large event, and this can mask the important structures where major earthquakes occur. Also, in hypocenter cross sections, events are generally projected over distances of $10 \mathrm{~km}$ or more onto the plane of section. Many of these events may be related to structures that are not present in the plane of the section, or which intersect it in a completely different place from where the events are projected. The advantages of using the cumulative energy release method are that zones of high-magnitude earthquakes are readily distinguished and imaged in situ. Following this, we assume that the highs in cumulative energy release are related to earthquakes taking place along major faults. A limitation of the cumulative energy release modeling is the recurrence time of earthquakes, which can significantly bias the results locally and may account for areas of low-energy release. 

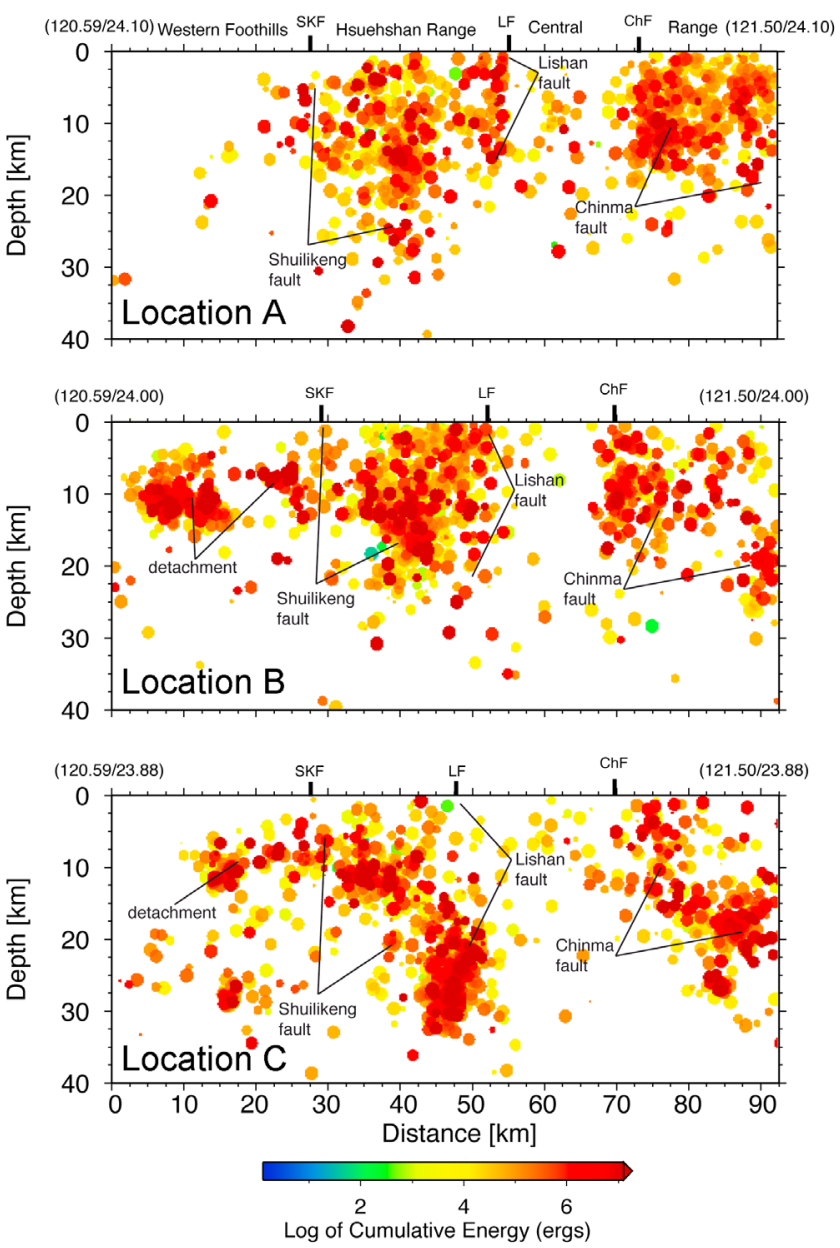

Figure 12. Seismic energy release sections. The sections labeled $\mathrm{A}, \mathrm{B}$, and $\mathrm{C}$ and their locations are shown in Figure 11. SKF $=$ Shuilikeng fault, $\mathrm{LF}=$ Lishan fault, $\mathrm{ChF}=$ Chinma fault.

[39] For our seismic energy release modeling in central Taiwan, 34,819 events of $>\mathrm{M}_{\mathrm{L}}=2$ were extracted from the 1991 to 2008 database of relocated earthquakes [e.g., $W u$ et al., 2008a] (Data Set S2). In accordance with the Taiwan Central Weather Bureau Seismic Network Earthquake Catalogue [Shin, 1993], the local magnitude $\mathrm{M}_{\mathrm{L}}$ is used to compute the seismic energy release (E, units are in ergs) for each event using the empirical relation

$$
\log \mathrm{E}=9.4+2.14 \mathrm{M}_{\mathrm{L}}-0.054 \mathrm{M}_{\mathrm{L}} * 2
$$

of Gutenberg and Richter [1956]. The relation used by Jeng et al. [2002] to study the energy release in the Taiwan subduction zones has also been tested, but without any significant change in the results. In this study, cumulative seismic energy release was determined in a 3-D volume using a discretized $100 \mathrm{~m}$ grid in which the energy is summed for all events that are located within a sphere of $2 \mathrm{~km}$ diameter centered at each grid point. Horizontal and vertical slices were then cut through the volume.

\subsubsection{Seismic Energy Release in Central Taiwan}

[40] The seismic energy released in the Western Foothills is scattered throughout the upper $30 \mathrm{~km}$ of crust, with minor amounts being released to a depth of at least $40 \mathrm{~km}$ (Figures 11 and 12). There is a marked high that is centered at about $10 \mathrm{~km}$ depth $( \pm 5 \mathrm{~km})$ in the central and southern part of the map area, and a lesser high along its eastern flank (Figures 11 and 12). The high centered at $\sim 10 \mathrm{~km}$ depth approximately coincides with the beginning of the low $\mathrm{P}$ wave velocity perturbation that marks the top of the Peikang basement high [ $\mathrm{Wu}$ et al., 2007]. This high in energy release can be interpreted to image the basal detachment of the Changhua-Chelungpu imbricate thrust system (Figures 11, $12 \mathrm{~b}$, and $12 \mathrm{c})$. The relative increase in cumulative energy release in the upper $10 \mathrm{~km}$ of crust along the eastern flank of the Western Foothills seems to be related to earthquakes occurring along Chelungpu and Shuangtung thrusts. There is a scattering of energy release to $\sim 40 \mathrm{~km}$ beneath the Western Foothills. While this is obviously related to elastic strain release within the Peikang basement high, we cannot associate it with any particular faults.

[41] There is an abrupt increase in cumulative energy release from the Western Foothills to the Hsuehshan Range that reaches a depth of $\sim 30 \mathrm{~km}$ (Figures 11 and 12). Along the western flank of the Hsuehshan Range, the increase in cumulative energy release dips steeply eastward and projects to the surface at the location of the Shuilikeng fault (Figures 11 and 12). Along its eastern flank, there is a steeply westward dipping to vertical truncation of energy release that projects to the surface at the location of the Lishan fault (Figure 11). In the southeastern part of the map area (Figures 11 and 12c), from $\sim 20$ to $35 \mathrm{~km}$ depth, there is a steeply west dipping high in the cumulative energy release that also projects to the Lishan fault at the surface. The highenergy release in the central part of the Hsuehshan Range is likely due to activity along the mapped faults that splay off the Shuilikeng fault (Figure 11).

[42] In the western part of the Central Range, the seismic energy release is relatively low and is scattered throughout the crust to a depth of at least $40 \mathrm{~km}$. With the present data set we are unable to determine any relationship between cumulative seismic energy release and geological structures in the western part of the Central Range. Eastward, there is an abrupt increase in the amount of energy being released in the upper 20 to $30 \mathrm{~km}$ of crust. This area corresponds to the Western Metamorphic Shear Zone of Gourley et al. [2007], who suggest that it is a steeply west dipping oblique extensional fault. At the surface, however, the western margin of this high coincides with the location of the Chinma fault (Figures 11 and 12 ), the $\sim 60^{\circ}$ eastward dipping shear zone that is transporting the Mesozoic and older crystalline basement rocks westward over the Paleogene and younger rocks to the west.

\section{Discussion}

\subsection{Structure and Fault Kinematics}

[43] The surface geological mapping presented here indicates that in Central Taiwan, from the buried Changhua thrust in the west to the Tananao Unit in the east, the mountain belt can be divided into six distinct, roughly northeast-southwest trending fault-bounded units (Figure 4). In this section we bring together the geological and geophysical data to discuss the crustal structure of these units and the kinematics of their bounding faults. 
[44] The surface geological data and the cumulative seismic energy release data presented here both corroborate the previous interpretations of a gently eastward dipping detachment at about 7 to $10 \mathrm{~km}$ depth below the Western Foothills (Figure 5) [e.g., Suppe, 1980, 1981; Ding et al., 2001; Carena et al., 2002; Yue et al., 2005]. For an alternative interpretation in which there is extensive basement involvement see, for example, Mouthereau and Petit [2003], Mouthereau and Lacombe [2006], and Simoes et al. [2007b] (and section 5.3). The differences in the depth to the detachment between the various data sets is a result of the uncertainties in the methodology of cross section construction, the choice of migration velocities and lack of a clear reflection in the seismic profile (Figure 6), and in the location of seismic events in the energy release data (Figure 12). Like the previous interpretations mentioned above, to the north of the Choshui River we place the detachment to the Changhua-Chelungpu imbricate thrust system within the Chinshui shale member of the Cholan Formation synorogenic sediments. South of the Choshui River, however, there is a significant change in the location of this basal thrust as it ramps down section into the older Miocene rocks, placing them on top of Pleistocene rocks in the Neilin anticline (Figure 2) [see also Mouthereau and Lacombe, 2006]. The seismicity data show that all types of fault mechanisms are active within this imbricate thrust system and along the detachment (Figure 10), indicating that it has complex kinematics and therefore a pure thrusting mechanism cannot be assumed [see also Wu et al., 2010]. These data, together with rare kinematic indicators found in the field and the horizontal component of the surface displacements determined from the GPS data [e.g., Yu et al., 2003; Bos et al., 2003; Lin et al., 2010], all indicate that a top-to-thenorthwest (oblique) sense of movement is taking place.

[45] We recognize that there are problems in interpreting the geometry of the Shuangtung thrust at depth (see section 3.3). On the basis of this study, we suggest that since it cuts down section through the Miocene and into Eocene age Paileng Formation rocks it is more likely to be structurally and kinematically linked to the Sun-Moon Lake Unit, although its eastern flank has been cut by the Shuilikeng fault. With the current data, however, it is not possible to determine the nature of this linkage. A possible example of how a frontal imbricate thrust system links with a regional transpressive fault system comes from the South Island of New Zealand [e.g., Walcott, 1998]. In the surface geology, the Shuangtung thrust places Miocene rocks on top of the upper part of the Toukoshan Formation, indicating that it was active during the late Pleistocene to Holocene. The seismic energy release in the shallow subsurface beneath the Shuangtung Unit, together with aftershocks of the Chi-Chi earthquake [R.-Y. Chen et al., 2002] suggest that the Shuangtung thrust is currently active [see also Sung et al., 2000].

[46] Unlike the previous interpretations in which the Western Foothills detachment extends eastward beneath the Hsuehshan and Central Ranges [e.g., Carena et al., 2002; Yue et al., 2005], we suggest that it appears to be truncated by, or is perhaps somehow linked with, the Shuilikeng fault zone. (Figures 5 and 12). See, for example, the aftershocks that occurred within the first $24 \mathrm{~h}$ of the Chi-Chi earthquake [Chang et al., 2007]. The data presented here indicate that the Shuilikeng fault, rather than being a single discrete feature, comprises a system of faults and folds that splay off the main fault, resulting in a regional map pattern that is strongly suggestive of a transpressive or strike-slip system fault zone (for examples of these types of map patterns, see Sylvester [1988], Butler et al. [1998], Walcott [1998], Kirkpatrick et al. [2008], Murphy et al. [2011], and Leever et al. [2011]). This Shuilikeng fault "system" dominates the structure of the Sun-Moon Lake Unit in the map area. The bending of folds (e.g., the Tingkan syncline or the Tsukeng anticline), together with the bending and truncation of the Tili Unit, against the Shuilikeng fault indicates that it has a sinistral component of displacement (Figure 2). However, earthquake focal mechanisms determined for the Sun-Moon Lake Unit show that the Shuilikeng fault "system" displays complex kinematics, with a clear range from strike-slip and "other" mechanisms in the upper $\sim 15 \mathrm{~km}$ of crust in the north, to predominantly thrusting at deeper levels in the southern part. Beginning at the southern margin of our map area and continuing farther south, Chang et al. [2007] and Wu et al. [2010] show that the dominant focal mechanism along the Shuilikeng fault is strike slip. The seismic energy release data show that Shuilikeng fault coincides with a significant, eastward deepening of the seismicity beneath the Hsuehshan Range (Figure 12), so we therefore interpret the fault zone to dip steeply eastward and to extend to at least 25 to $30 \mathrm{~km}$ depth. Geomorphological data indicate that the Shuilikeng fault has been active throughout the Holocene and continues to be so [Sung et al., 2000; Yanites et al., 2010]. Aftershocks that took place within the first $24 \mathrm{~h}$ after the Chi-Chi earthquake also indicate that the Shuilikeng fault is active [cf. Chang et al., 2007].

[47] The Tili thrust marks a clear structural and metamorphic boundary in the Hsuehshan Range. It juxtaposes lower metamorphic grade rocks of the Sun-Moon Lake Unit against higher-grade rocks with a well-developed cleavage in the Tili Unit. It also represents an abrupt change in structural style from the Sun-Moon Lake Unit, with tighter, west vergent fault propagation folding becoming dominant and a well-developed axial planar cleavaged being developed. From the data presented here we cannot discriminate the geometry or the kinematics of the Tili thrust.

[48] In this paper we identify a clearly defined zone of intense ductile strain that coincides with the location of the Lishan fault. This high-strain zone, together with the recent finding of large foraminifera that are assigned to the NP14 biozone [Chen et al., 2009] in rocks along the western side of the Lishan fault confirm that it juxtaposes early to middle Eocene higher metamorphic grade rocks of the Tili Unit against middle Miocene lower metamorphic grade rocks of the Lushan Unit [see also Clark et al., 1993; Lee et al., 1997; Wu et al., 2004; Beyssac et al., 2007; Bertrand et al., 2009, 2012; Simoes et al., 2012]. Surface structural data and the seismic energy release data indicate that it is a vertical to steeply west dipping structure that extends to $\sim 35 \mathrm{~km}$ depth (Figure 12) [see also Clark et al., 1993; Tillman and Byrne, 1995; Wu et al., 2004; Chang et al., 2007; Bertrand et al., 2009, 2012]. This interpretation of the dip and depth of penetration of the Lishan fault is also justified by the pronounced gradient across it in the Bouguer gravity anomaly, from a low beneath the Hsuehshan Range to a high beneath the Central Range [Wu et al., 1997; Yen et al., 1998; Hwang 
et al., 2007]. Locally, rare kinematic indicators point to a sinistral sense of movement, whereas focal mechanism data indicate that the overall kinematics are quite complex [Wu et al., 2004; Chang et al., 2007; Wu et al., 2010]. Modeling of GPS data suggests that it has a sinistral sense of slip [Bos et al., 2003]. These data, together with the seismic activity along parts of the Lishan fault in our map area (Figures 11 and 12) indicate that it is currently active.

[49] To the east of the Lishan fault, the Lushan Unit displays highly nonclyndrical folding. In general, the structure displays an overall northwest vergence, which we can determine from the well developed, moderately southeast dipping cleavage. This is in agreement with the kinematics determined by Tillman and Byrne [1995] and Fisher et al. [2002]. The low P wave velocity modeled in the shallow subsurface beneath the Lushan Unit [Rau and $W u, 1995 ; \mathrm{Wu}$ et al., 2007; Kuo-Chen et al., 2012] suggests that the unit is on the order of 3 to $5 \mathrm{~km}$ thick. However, because of the lack of seismicity in this part of the Central Range, it is not possible to determine the deep subsurface structure.

[50] We have very few geological data from the Tananao Unit, which is being thrust westward over the Lushan Unit along the Chinma fault (Figure 2). To the east of this fault there is extensive seismic energy release to a depth of at least $30 \mathrm{~km}$. The change in seismicity from the Lushan to the Tananao Unit is near vertical, which led Gourley et al. [2007] to suggest that the Chinma fault dips steeply westward. However, this fault outcrops very well along the Central Cross Island Highway, where it clearly dips $\sim 60^{\circ}$ to the southeast [see also Tillman and Byrne, 1995]. The focal mechanism data show that the upper $10 \mathrm{~km}$ of crust in the Tananao Unit is dominated by extension [see also Crespi et al., 1996], whereas thrusting is dominant below this.

[51] Finally, in our map area we identify two areas in which there are important changes in the structural trend. For example, to the north of the Paikang River there is a systematic change in the orientation of structures from a roughly northerly trend to a more easterly trend along the Tachia River (Figure 2). This can be seen to affect individual structures, such as the Hsiaoan anticline (Figure 2) which becomes turned up on its end along the Tachia River. There is also a marked change in the earthquake focal mechanisms, with strike-slip faults becoming more important northward (Figure 10). A second such structure appears to affect the area immediately south of the Choshui River. North of the river, the regional trend of fold axes has an overall southerly plunge, whereas south of the river it takes on a northerly plunge (Figure 8). Also, the Tili Unit is offset dextrally to the south of the river (Figure 2). Southward, the Chelungpu thrust clearly ramps down into deeper and older stratigraphy, moving it westward over the top of the Neilin anticline.

\subsection{Sequence of Deformation}

[52] Based on overprinting relationships within our map area, we suggest a deformation sequence for mountain building in this part of Taiwan that consists of two phases (D1 and D2) (Figure 13). The onset of D1 takes place with the arrival of the Eurasia continental margin at the subduction zone (Figure 13a). The Eurasia margin in the Taiwan area is well known to contain several large rift basins [e.g., Teng, 1990, 1992; Huang et al., 2001; Teng and Lin, 2004; Lin and Watts, 2002; Lin et al., 2003] that have been variably affected by the deformation related to the Taiwan orogeny. In Figure 13 we give a schematic representation of what the Taiwan part of the margin could have looked like and what the distribution of the preorogenic sediments involved in the deformation may have been at time T0. Note that we represent the Hsuehshan Basin as a graben structure rather than a half graben as suggested by Teng et al. [1991] and Teng and Lin [2004]. This allows for easier reconstruction of the original position of the Tili Unit by letting us place the D1 detachment near the top of the prerift basement (Figure 13b). It also provides an explanation for the nature and presence of the Peikang basement high (see also Figure 1).

[53] We interpret the earliest deformation (D1) associated with the Taiwan orogeny in our map area to be the development and emplacement of the Tili and Lushan Units at time T1, when the extended continental margin had entered into the subduction zone (Figure 13b). It is difficult to accurately constrain the age and timing of emplacement of these units, but the first appearance of lithic clasts containing a cleavage in the fore-arc region of the Coastal Range and in the Western Foothills foreland basin sediments occurred during the early Pliocene, or some 3.5 to $4 \mathrm{Myr}$ ago [Lee, 1963; Chi et al., 1981; Covey, 1986; Dorsey, 1987; Teng, 1987, 1990; Huang et al., 2006]. This indicates that rocks with a cleavage (i.e., the Tili and Lushan Units) were exhumed and being eroded by this time. Consequently, the leading edge of the continental margin must have entered into the subduction zone at some time prior to the early Pliocene if these units where to be deformed and emplaced by this time. A further indication that the deformation and emplacement of the Tili and Lushan Units is one of the earliest events recorded in the map area is given by the geometric relationships between the rocks in these units and faults. For example, the Tili Unit is cut by the Shuilikeng fault system in the southwest (Figure 2) and appears to be cut by the Lishan fault in the northeast (just out of the current map area). Similarly, along its western flank the Lushan Unit is cut by the Lishan fault and, in the east, by the Chinma fault. These geometric relationships indicate that activity along the Shuilikeng, Lishan, and Chinma faults must postdate the early emplacement of the Tili and Lushan Units. We therefore suggest that, despite the different metamorphic conditions undergone by the Tili and Lushan Units, that there is a close enough similarity in the structural style and in the orientations of bedding and cleavage between the two to interpret that they developed as a roughly NW vergent thrust stack at the same time, early on in the history of the Taiwan mountain belt, and that they were both being emplaced by at least the early Pliocene. This is in contrast to the model presented by Tillman and Byrne [1995], for example, who suggest that these units were emplaced in two distinct phases of deformation. The Tili and Lushan Units were subsequently breached by, and juxtaposed along, the Lishan fault at some unknown time. From our data we interpret the Tili and Lushan Units to now be inactive.

[54] The next phase of the deformation sequence in the study area (D2) is interpreted to be related to reactivation of preexisting extensional faults as the full thickness of the continental margin arrived at the subduction zone (T2 in Figure 13). This resulted in the formation of the Chinma fault, the Lishan fault, the Shuilikeng fault system, and the 
emplacement of the Shuangtung Unit and the ChanghuaChelungpu imbricate thrust system. D2 structures are currently active and, to the east of the Shuilikeng fault, form a regional-scale basement culmination (Figure 13c). In this scenario, the Hsuehshan Range forms a zone of transpression with a structural architecture similar to that of a crustal- scale positive flower (or pop-up) structure that is bound by the Shuilikeng and Lishan faults (Figure 5), and in which there is a large amount of seismic activity and seismic energy release (Figures 12 and 13). This structural architecture was first proposed by Clark et al. [1993] based on observations in the Tili and Lushan Units in the NE part of

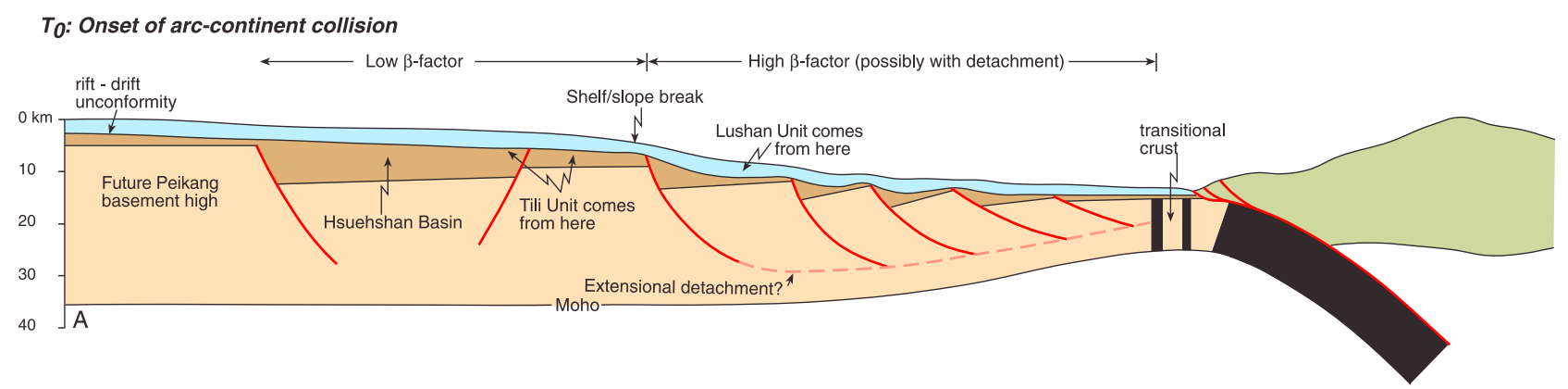

$T_{1}$ : Emplacement of Tili and Lushan units
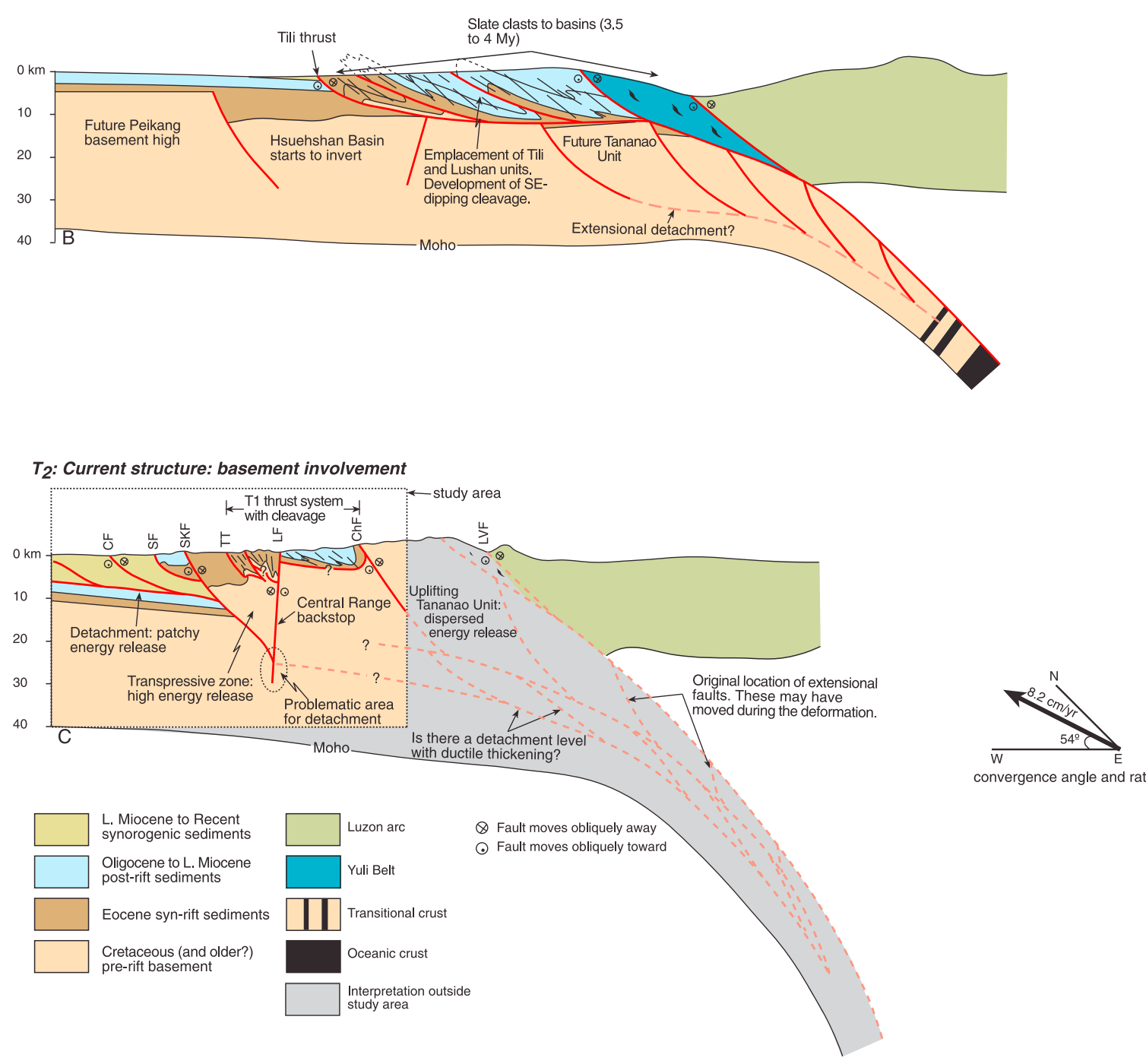

Figure 13 
our map area (Figure 2). Our data suggest that a transpressional structural architecture is developed throughout the Hsuehshan Range between at least the Tachia River in the North and the Choshui River in the South. Farther to the south of our map area, the Shuilikeng fault and the Lishan fault merge, although little is known about how these faults interact at the surface. Nevertheless, the geological and focal mechanism data indicate that they are both steeply dipping features with complex kinematics that extend well into the middle and perhaps even the lower crust (Figure 13). Furthermore, the seismic energy release data suggest that they interact at depth (Figure 11), possibly with the Lishan fault extending deeper into the crust than does the Shuilikeng fault (Figure 13c). It is not possible to constrain when this fault system became active.

[55] As indicated in section 5.1., we are uncertain how the Shuangtung thrust links with the Changhua-Chelungpu imbricate system and with this transpressive structure. The presence of Eocene rocks in the Shuangtung Unit suggests that the Shuangtung thrust may have developed as a footwall shortcut fault that was linked to, and eventually cut by the Shuilikeng fault. See Narr and Suppe [1994] for theoretical and real examples of how these structures develop. On the basis of foreland basin sedimentation, geomorphic structures, and magnetostratigraphy, W.-S. Chen et al. [2000, 2001a], Simoes and Avouac [2006], and Simoes et al. [2007a, 2007b] suggest a forward breaking fault sequence, in which the Shuangtung thrust became active at circa 1.1 Ma, the Chelungpu thrust at 0.7 to $0.9 \mathrm{Ma}$., and the Changhua at 0.62 to $0.65 \mathrm{Ma}$.

[56] Uplift and erosion of the Tananao Unit along the Chinma fault appears to have been taking place by at least the latest Pleistocene $(1.4 \mathrm{Ma})$, depositing metamorphic clasts into the fore-arc basin in the Coastal Range [Dorsey, 1987]. Zircon and apatite fission track ages [e.g., Liu et al., 2001; Lee et al., 2006; Fuller et al., 2006] also indicate that the Tananao Unit was being exhumed by the early part of the Pleistocene. At the Chinma Tunnel, along the Central Cross Island Highway, the Tananao Unit clearly overthrusts the Lushan Unit providing unequivocal evidence that it postdates the emplacement of this later unit. Extensive seismicity indicates that the Chinma fault is still active.

\subsection{Tectonic Implications for the Orogen Architecture}

[57] On the basis of the data presented here, we agree with previous authors [e.g., Suppe, 1980, 1981; Namson, 1981;
Ding et al., 2001; Carena et al., 2002; Yue et al., 2005] that in our map area the Changhua-Chelungpu imbricate thrust system is structurally linked to a basal detachment at the base of the synorogenic sediments in the foreland basin. Southward, involvement of the Miocene in the thrusting indicates that this basal thrust ramps downward in the stratigraphy (Figure 2) [e.g., Hickman et al., 2002; Mouthereau et al., 2002; Mouthereau and Lacombe, 2006]. These data also suggest, however, that a structural and kinematic model in which the Hsuehshan Range forms a deep-rooted zone of transpression between the Shuilikeng and Lishan faults better fits the available data than that of an imbricate thrust system with a shallow, throughgoing detachment. Depending on the estimation of the Moho depth [e.g., Rau and Wu, 1995; McIntosh et al., 2005; Wu et al., 2007], the Lishan fault may be interpreted to cut nearly the entire crust (Figure 13c). In this scenario, the Hsuehshan Range and its bounding faults take up a significant amount of the oblique arc-continent convergence within the Eurasian margin [see also Mouthereau et al., 2009; Hsu et al., 2009; Wu et al., 2010], with the western part of the Central Range acting as a vertical to steeply west dipping backstop to the transpressional belt [see also Clark et al., 1993; Yamato et al., 2009; Mouthereau et al., 2009]. A corollary to this is that there is no structural linkage in the form of a detachment between the Hsuehshan and Central Ranges, and therefore no (or very limited) material transfer across the Lishan fault into the Central Range as has been suggested by others [e.g., Fuller et al., 2006; Simoes et al., 2007b; Fisher et al., 2007; Bertrand et al., 2012]. East of the Lishan fault, the Central Range can be interpreted to be deforming by inversion of preexisting extensional faults that affect the prerift basement (Tananao Unit) (Figure 13c). A key question that arises is whether or not these reactivated faults are linked to a deep detachment level beneath the Central Range.

[58] Using geological data and modeling approaches various authors [e.g., Tillman and Byrne, 1995; Simoes et al., 2007a; Yamato et al., 2009; Mouthereau et al., 2009; Ching et al., 2011b] have suggested that there is a basal detachment in the middle to lower crust beneath the Hsuehshan and Central Ranges. This detachment is thought to either cut steeply $\left(17^{\circ}\right)$ upsection toward the west with (or without) significant underplating taking place [e.g., Simoes et al., 2007a; Ching et al., 2011b], to remain as a subhorizontal feature in the lower crust before ramping steeply upsection toward the mountain front [e.g., Yamato et al., 2009;

\footnotetext{
Figure 13. Schematic evolutionary model for the development of the Taiwan mountain belt. (a) The onset of arc-continent collision. The interpreted precollisional locations of the units described in the text are shown. The extensional detachment is interpreted for the outermost margin where there was likely to have been a high $\beta$ factor [McKenzie, 1978]. The Yuli Belt, which is not mentioned in the text, is the eastern part of the Tananao Unit and is interpreted to be part of the Late Cretaceous basement [e.g., Yui et al., 2012]. (b) The late Miocene to early Pliocene emplacement, uplift and erosion of the Tili and Lushan Units. The amount of displacement and thrust sheet stacking represented are purely interpretative. (c) The current structure in a W-E oriented section along section $\mathrm{C}-\mathrm{C}^{\prime}$ in Figure 5 and eastward across the Central and Coastal Ranges, into the arc. The location of our study area is indicated by the dashed box and in color. To the east of the study area, shown in gray, the structure is purely interpretive. The location of a possible deep detachment beneath the Central Range is indicated. Also indicated is the problematic area for the extrapolation of a detachment across the Lishan fault. The convergence vector is from Yu et al. [1997] and is only for T2. The Moho is an interpretation based on the velocity models of Rau and $W u$ [1995], McIntosh et al. [2005], Wu et al. [2007], and Ustaszewski et al. [2012]. CT = Chelungpu thrust, ST = Shuangtung thrust, $\mathrm{SKF}=$ Shuilikeng fault, $\mathrm{LF}=$ Lishan fault, $\mathrm{ChF}=$ Chinma fault, $\mathrm{LvF}=$ Longitudinal Valley fault.
} 
Mouthereau et al., 2009], or to be the result of a second phase of deep level thrusting that ramps stepwise upsection toward the deformation front [Tillman and Byrne, 1995]. While all of these models present viable possibilities for a deep basal detachment, most do not take into account the significance of a deeply penetrating Lishan fault (except Tillman and Byrne [1995]) (see Figure 13), and do not fully take into account the preexisitng three-dimensional structure of the continental margin.

[59] How a continental margin deforms during convergence depends to a large degree on its preexisting structural architecture, and how this is oriented relative to the convergence vector [e.g., Dewey et al., 1986; Brown et al., 1999, 2011; Manatschal, 2004; Mohn et al., 2010; Byrne et al., 2011; Reston and Manatschal, 2011; Harris, 2011]. Geological and geophysical data from a number of continental margins and mountain belts worldwide have shown that the rift architecture can be very complex and can include an extensional detachment below the outer margin where there is a high $\beta$ factor [e.g., Reston et al., 1996; Manatschal, 2004; Mohn et al., 2010; Reston and Manatschal, 2011]. Reactivation of preexisting basement faults and the inversion of sedimentary basins along a margin can control the location, geometry, and kinematics of structures in the developing mountain belt including the basal detachment, and will often result in the development of lateral structures, basement involvement in thrust sheets, and the formation of basement culminations [e.g., Laubscher, 1987; Glen, 1985; Hatcher and Williams, 1986; Rodgers, 1987; Woodward, 1988; Schmidt et al., 1988; Bryant and Nichols, 1988; Cooper and Williams, 1989; Narr and Suppe, 1994; Wibberley, 1997; Perez-Estaun et al., 1997; Butler et al., 1997; Brown et al., 1997, 1999, 2006; Oncken et al., 1999; Manatschal, 2004; Mohn et al., 2010; Reston and Manatschal, 2011]. The Eurasian margin involved in the deformation of the Taiwan mountain belt has been shown to have contained a number of deep extensional basins that were active throughout the Eocene, Oligocene, and Miocene [Lin et al., 2003; Teng and Lin, 2004; Teng, 1987; Huang et al., 1997, 2001; Byrne et al., 2011] (Figure 1). The importance of these features on the development of the three-dimensional structure of the Taiwan mountain belt is well known [e.g., Wu et al., 1997; Mouthereau et al., 2002; Mouthereau and Lacombe, 2006; Wu et al., 2007; Hwang et al., 2007; Byrne et al., 2011] although still not completely understood. It is possible, therefore, that an hypothetical extensional detachment beneath what was the outer margin is now being reactivated to form a level of deep detachment beneath the Central Range (Figure 13). This detachment may be a zone of ductile thickening (underplating in the models of Simoes et al. [2007a] and Ching et al. [2011b]) in the form of duplexing and/or thrust stacking of extensional fault blocks. We stress, however, that with the current data sets it is not possible to unequivocally define such a detachment level beneath the Central Range, and very difficult to extend it westward across the Lishan fault and below the Hsuehshan Range to link it with the Changhua-Chelungpu imbricate thrust system (Figure 13).

[60] An alternative model for the development of the Taiwan Orogen is the "lithosphere plate collision" model of Wu et al. [1997] in which there is no subduction of the Eurasian margin beneath the Luzon arc, the Central Range appears as a completely different lithology from the zones to the west, and there is no detachment beneath the Taiwan mountain belt. In this model, the Eurasian margin is indenting the Luzon arc and is deforming along steep faults that locally involve the whole crust and upper mantle. While it is commonly accepted that the whole lithosphere is involved in plate tectonics, including subduction and collision systems [e.g., Gerya, 2011; Afonso and Zlotnik, 2011], the overall rheological and structural model put forward by Wu et al. [1997, Figure 16] for the deforming continental crust in Taiwan does not appear to fit well with the currently available geological, thermochonological, and geophysical data. Nor does it fit well with the tectonic processes determined from other well known examples from either fossil or active arc-continent collisions [see, e.g., Brown and Ryan, 2011, and references therein]. Nevertheless, it does bring to the forefront the problems associated with the interpretations of, for example, the Lishan fault (or even its existence), and the need to provide a geological model for the evolution of the Taiwan mountain belt that accounts for the deep crustal seismicity.

\section{Conclusions}

[61] This paper presents new geological mapping in the Western Foothills, the Hsuehshan Range, and the western part of the Central Range in central Taiwan that, together with earthquake focal mechanism and seismic energy release data, place constraints on the structural architecture, fault kinematics, and relative timing of the development of the Taiwan mountain belt. On the basis of similarities in structure, stratigraphy, and kinematics the Western Foothills, Hsuehshan Range, and Central Range can be further subdivided into six fault-bound units. Structural overprinting relationships between these units shows that the Taiwan mountain belt has evolved during at least two distinct, but progressive phases in the deformation sequence. The recognition of these two phases is essential for determining the crustal-scale structural evolution of the mountain belt.

[62] The first stage of deformation (D1) took place during the late Miocene to early Pliocene and emplaced slope sediments northwestward to form a thrust stack with the Tili and Lushan Units (Figure 13). Both these units underwent a distinct metamorphic grade and deformation style that includes a penetrative pressure solution cleavage [e.g., Clark et al., 1993; Tillman and Byrne, 1995; Fisher et al., 2002; Beyssac et al., 2007; Simoes et al., 2012]. The Tili and Lushan Units began to provide clasts to the foreland and fore-arc basins by the early Pliocene [e.g., Covey, 1986; Dorsey, 1987], thereby placing an upper limit on the age of the earlier deformation of the Taiwan mountain belt. Our data suggest that D1 structures are no longer active.

[63] The second phase of deformation (D2) is interpreted, in part, to involve the reactivation of preexisting extensional faults on the continental margin and slope to form a basement culmination. These faults clearly cut the D1 structures [see also Clark et al., 1993; Tillman and Byrne, 1995; Lee et al., 1997]. Our data show that D2 structures are currently active and are responsible for the development of a transpressional zone within the Hsuehshan Range that is bound by the Lishan fault in the east and the Shuilikeng fault system in the west. The imbricate thrust system of the Western 
Foothills is linked to this transpressional zone and is active. Uplift of the Tananao unit in the east [see Dorsey, 1987] is coeval with the transpressive deformation in the Hsuehshan Range and the Western Foothills.

[64] A consequence of the recognition of the two phase deformation sequence in the Taiwan mountain belt is that it did not everywhere develop as a forward breaking imbricate thrust system with a shallowly eastward dipping basal detachment in the upper crust [e.g., Suppe, 1980, 1981; Ding et al., 2001; Carena et al., 2002; Yue et al., 2005; Malavieille and Trullenque, 2009]. Nevertheless, the data presented here do support the interpretations by these authors of an imbricate thrust system (the ChanghuaChelungpu imbricate thrust system) within the foreland basin sediments of the Western Foothills, but it also shows that this thrust system is related to the D2 deformation sequence. The data do not support the extrapolation of an imbricate thrust system structural architecture eastward into the Hsuehshan and Central Ranges. Instead, the data suggest that the D2 transpressive fault system active in the Hsuehshan Range is deeply rooted, affecting nearly the entire crust. A corollary to this is that the orogen does not have a wedge-shaped structural architecture with throughgoing basal detachment that links the entire mountain belt from the Changhua thrust in the west to below the Central Range in the east. It is possible, however, with our data to interpret a deep detachment level beneath much of the Central Range (Figure 13c), as some authors have already indicated [e.g., Tillman and Byrne, 1995; Simoes et al., 2007a; Yamato et al., 2009; Mouthereau et al., 2009; Ching et al., 2011b]. This hypothetical detachment may have formed by the reactivation of an earlier extensional detachment that had developed on the outer slope of the margin, in the area with a high $\beta$ factor (Figure 13).

[65] Finally, in our map area we identify two areas in which there are important changes in the structural trend: (1) to the north of the Paikang River there is a systematic change in the orientation of structures from a roughly northerly trend to a more easterly trend along the Tachia River and (2) immediately south of the Choshui River there is a change in the regional trend of fold axes, and the Chelungpu thrust ramps down into deeper and older stratigraphy. We interpret these changes in structure to be caused by the reactivation of preexisitng basement faults that are related to the Tainan and Taishi basins [see also, e.g., Mouthereau et al., 2002; Mouthereau and Lacombe, 2006; Byrne et al., 2011].

[66] Acknowledgments. This research was carried out with the aid of grants by CSIC-Proyectos Intramurales 2006301010 , and MICINN: CGL2009-11843-BTE. We would like to thank the Department of Earth Sciences, NCKU, Tainan, for its support of students during field work. We are especially indebted to Her Dai-Jie, Chien Chih-Wei, E Justin, and of course Huang Chi-Yue. We also want to thank the Central Geological Survey, in particular, Chu Hao-Tsu and Chen Mien-Ming for all of their help and advice. M. Simoes kindly provided the reflection seismic profile. Reviews of this manuscript by F. Mouthereau, T. Byrne, E. Casciello, and an anonymous reviewer helped to clarify a number of ideas.

\section{References}

Afonso, J. C., and S. Zlotnik (2011), The subductability of the continental lithosphere: The before and after story, in Arc-Continent Collision, edited by D. Brown and P. D. Ryan, pp. 53-86, Springer, New York.

Bertrand, E., M. Unsworth, C.-W. Chiang, C.-S. Chen, C.-C. Chen, F. Wu, E. Türkoglu, H.-L. Hsu, and G. Hill (2009), Magnetotelluric evidence for thick-skinned tectonics in central Taiwan, Geology, 37, 711-714, doi:10.1130/G25755A.1.

Bertrand, E., M. Unsworth, C.-W. Chiang, C.-S. Chen, C.-C. Chen, F. Wu, E. Türkoglu, H.-L. Hsu, and G. Hill (2012), Magnetotelluric imaging beneath the Taiwan orogen: An arc-continent collision, J. Geophys. Res., 117, B01402, doi:10.1029/2011JB008688.

Beyssac, O., M. Simoes, J. P. Avouac, K. A. Farley, Y.-G. Chen, Y.-C. Chan, and B. Goffé (2007), Late Cenozoic metamorphic evolution and exhumation of Taiwan, Tectonics, 26, TC6001, doi:10.1029/2006TC002064.

Bos, A. G., W. Spakman, and M. C. J. Nyst (2003), Surface deformation and tectonic setting of Taiwan inferred from a GPS velocity field, J. Geophys. Res., 108(B10), 2458, doi:10.1029/2002JB002336.

Brown, D., and P. D. Ryan (Eds.) (2011), Arc-Continent Collision, 493 pp., Springer, New York.

Brown, D., J. Alvarez-Marron, A. Perez-Estaun, Y. Gorozhanina, V. Baryshev, and V. Puchkov (1997), Geometric and kinematic evolution of the foreland thrust and fold belt in the southern Urals, Tectonics, 16, 551-562, doi:10.1029/97TC00815.

Brown, D., J. Alvarez-Marron, A. Perez-Estaun, V. Puchkov, and C. Ayala (1999), Basement influence on foreland thrust and fold belt development: An example from the southern Urals, Tectonophysics, 308, 459-472, doi:10.1016/S0040-1951(99)00147-X.

Brown, D., P. Spadea, V. Puchkov, J. Alvarez-Marron, R. Herrington, A. P. Willner, R. Hetzel, and Y. Gorozhanina (2006), Arc-continent collision in the southern Urals, Earth Sci. Rev., 79, 261-287, doi:10.1016/ j.earscirev.2006.08.003.

Brown, D., et al. (2011), Arc-continent collision: The making of an orogen, in Arc-Continent Collision, edited by D. Brown and P. D. Ryan, pp. 477-493, Springer, New York.

Bryant, B., and D. J. Nichols (1988), Late Mesozoic and early Tertiary reactivation of an ancient crustal boundary along the Uinta trend and its interaction with the Sevier orogenic belt, in Interaction of the Rocky Mountain Foreland and Cordilleran Thrust Belt, edited by C. J. Schmidt and W. J. Perry, Mem. Geol. Soc. Am., 171, 411-430.

Butler, R. W. H., R. E. Holdsworth, and G. E. Lloyd (1997), The role of basement reactivation in continental deformation, J. Geol. Soc., 154, 69-71, doi:10.1144/gsjgs.154.1.0069.

Butler, R. W. H., S. Spencer, and H. M. Griffiths (1998), The structural response to evolving plate kinematics during transpression: Evolution of the Lebanese restraining bend of the Dead Sea transform, in Continental Transpressional and Transtensional Tectonics, edited by R. E. Holdsworth, R. A. Strachan, and J. F. Dewey, Geol. Soc. Spec. Publ., 135, 81-106.

Byrne, T., Y.-C. Chan, R.-J. Rau, C.-Y. Lu, Y.-H. Lee, and Y.-J. Wang (2011), The arc-continent collision in Taiwan, in Arc-Continent Collision, edited by D. Brown and P. D. Ryan, pp. 213-245, Springer, New York.

Carena, S., J. Suppe, and H. Kao (2002), Active detachment of Taiwan illuminated by small earthquakes and its control of first-order topography, Geology, 30, 935-938, doi:10.1130/0091-7613(2002)030<0935: ADOTIB $>2.0 . \mathrm{CO} ; 2$.

Chang, C.-H., Y.-M. Wu, T.-C. Shin, and C.-Y. Wang (2000), Relocating the 1999 Chi-Chi earthquake, Taiwan, Terr. Atmos. Oceanic Sci., 11, $581-590$.

Chang, C.-H., Y.-M. Wu, L. Zhao, and F. Wu (2007), Aftershocks of the 1999 Chi-Chi, Taiwan, earthquake: The first hour, Bull. Seismol. Soc. Am., 97, 1245-1258, doi:10.1785/0120060184

Chang, L.-S. (1976), The Lushanian stage in the Central Range of Taiwan and its fauna, in Progress in Micropaleontology, Selected Papers in Honor of Prof. Kiyoshi Asano, edited by Y. Takayanagi and T. Saito, pp. 27-55, Micropaleontol. Press, New York.

Chen, C.-H., et al. (2000), Geological map of Taiwan, scale 1:500,000, Cent. Geol. Sur., Taipei.

Chen, K.-C., B.-S. Huang, J.-H. Wang, and H.-Y. Yen (2002), Conjugate thrust faulting associated with the 1999 Chi-Chi, Taiwan, earthquake sequence, Geophys. Res. Lett., 29(8), 1277, doi:10.1029/2001GL014250.

Chen, M.-M., N.-T. Yu, H.-T. Chu, K.-S. Shea, and Y.-C. Hsieh (2009), Larger foraminifera in the so-called "Meichi Sandstone" of Wujie area, southern Hsuehshan Range, Spec. Publ. 22, pp. 227-242, Cent. Geol. Surv., Taipei.

Chen, R.-Y., H. Kao, C.-S. Chang, and K.-W. Kuo (2002), Determination of earthquake fault plane from strong-motion waveform inversion, paper presented at 9th Symposium on the Geophysics of Taiwan, Chin. Geophys. Union, Taipei.

Chen, W.-S., et al. (2000), The evolution of foreland basins in the western Taiwan: Evidence from the Plio-Pleistocene sequences, Bull. Cent. Geol. Surv., 13, 136-156.

Chen, W.-S., K. D. Ridgway, C.-S. Horng, Y.-G. Chen, K.-S. Shea, and M.-G. Yeh (2001a), Stratigraphic architecture, magnetostratigraphy, and incised valley systems of the Pliocene-Pleistocene collisional marine 
foreland basin of Taiwan, Geol. Soc. Am. Bull., 113, 1249-1271, doi:10.1130/0016-7606(2001)113<1249:SAMAIV>2.0.CO;2.

Chen, W.-S., et al. (2001b), 1999 Chi-Chi earthquake: A case study on the role of thrust-ramp structures for generating earthquakes, Bull. Seismol. Soc. Am., 91, 986-994, doi:10.1785/0120000731.

Chen, W.-S., Y.-G. Chen, R.-C. Shih, T.-K. Liu, N.-W. Huang, C.-C. Lin, S.-H. Sung, and K.-J. Lee (2003), Thrust-related river terrace development in relation to the 1999 Chi-Chi earthquake rupture, Western Foothills, central Taiwan, J. Asian Earth Sci., 21, 473-480, doi:10.1016/S13679120(02)00072-X

Chen, W.-S., et al. (2007), Late Holocene paleoearthquake activity in the middle part of the Longitudinal Valley Fault, eastern Taiwan, Earth Planet. Sci. Lett., 264, 420-437, doi:10.1016/j.eps1.2007.09.043.

Chi, W.-R., J. Namson, and J. Suppe (1981), Stratigraphic record of plate interactions in the Coastal Range of eastern Taiwan, Mem. Geol. Soc. China, 4, 491-530.

Ching, K.-E., R.-J. Rau, K. M. Johnson, J.-C. Lee, and J.-C. Hu (2011a), Present-day kinematics of active mountain building in Taiwan from GPS observations during 1995-2005, J. Geophys. Res., 116, B09405, doi:10.1029/2010JB008058.

Ching, K.-E., M.-L. Hsieh, K. M. Johnson, K.-H. Chen, R.-J. Rau, and M. Ying (2011b), Modern vertical deformation rates and mountain building in Taiwan from precise leveling and continuous GPS observations, 2000-2008, J. Geophys. Res., 116, B08406, doi:10.1029/2011JB008242.

Chiu, H.-T. (1975), Miocene stratigraphy and its relation to the Palaeogene rocks in west-central Taiwan, Pet. Geol. Taiwan, 12, 51-80.

Clark, M. B., D. M. Fisher, C.-Y. Lu, and C.-H. Chen (1993), Kinematic analyses of the Hsuehshan Range, Taiwan: A large-scale pop-up structure Tectonics, 12, 205-217, doi:10.1029/92TC01711.

Cooper, M. A., and G. D. Williams (1989), Inversion Tectonics, Geol. Soc. Spec. Publ., 44, 375 pp.

Covey, M. (1986), The evolution of foreland basins to steady state Evidence from the western Taiwan foreland basin, in Foreland Basins, edited by P. A. Allen and P. Homewood, Spec. Publ. Int. Assoc. Sedimentol., 8, 77-90, Oxford, U. K.

Crespi, J. M., Y.-C. Chan, and M. S. Swaim (1996), Synorogenic extension and exhumation of the Taiwan hinterland, Geology, 24, 247-250, doi:10.1130/0091-7613(1996)024<0247:SEAEOT>2.3.CO;2.

Dahlstrom, C. D. A. (1969), Balanced cross sections, Can. J. Earth Sci., 6, 743-757, doi:10.1139/e69-069.

Dewey, J. F., M. R. Hempton, W. S. F. Kidd, F. Saroglu, and A. M. C. Sengör (1986), Shortening of continental lithosphere: The neotectonics of eastern Anatolia-A young collision zone, in Collision Tectonics, edited by M. P. Coward and A. C. Ries, Geol. Soc. Spec. Publ., 19, 3-36.

Ding, Z.-Y., Y.-Q. Yang, Z.-X. Yao, and G.-H. Zhang (2001), A thinskinned collisional model for the Taiwan orogeny, Tectonophysics, 332, 321-331, doi:10.1016/S0040-1951(00)00289-4.

Dorsey, R. J. (1987), Provenance evolution and unroofing history of a modern arc-continent collision: Evidence from petrology of Plio-Pleistocene sandstones, eastern Taiwan, J. Sediment. Petrol., 58, 208-218.

Fisher, D. M., C.-Y. Lu, and H.-T. Chu (2002), Taiwan slate belt: Insights in the ductile interior of an arc-continent collision, in Geology and Geophysics of an Arc-Continent Collision, Taiwan, edited by T. B. Byrne and C.-S. Liu, Spec. Pap. Geol. Soc. Am., 358, 93-106.

Fisher, D. M., S. Willet, E.-C. Yeh, and M. B. Clark (2007), Cleavage fronts and fans as reflections of orogen stress and kinematics in Taiwan, Geology, 35, 65-68, doi:10.1130/G22850A.1.

Frohlich, C. (1992), Triangle diagrams: Ternary graphs to display similarity and diversity of earthquake focal mechanisms, Phys. Earth Planet. Inter., 75, 193-198, doi:10.1016/0031-9201(92)90130-N.

Frohlich, C. (2001), Display and quantitative assessment of distributions of earthquake focal mechanisms, Geophys. J. Int., 144, 300-308, doi:10.1046/j.1365-246x.2001.00341.x.

Fuller, C. W., S. D. Willet, D. Fisher, and C.-Y. Lu (2006), A thermomechanical wedge model of Taiwan constrained by fission-track thermochronometry, Tectonophysics, 425, 1-24, doi:10.1016/j.tecto.2006.05.018.

Gerya, T. (2011), Intra-oceanic subduction zones, in Arc-Continent Collision, edited by D. Brown and P. D. Ryan, pp. 23-52, Springer, New York.

Glen, R. A. (1985), Basement control on the deformation of cover basins: An example from the Cobar district in the Lachlan Fold Belt, Australia J. Struct. Geol., 7, 301-315, doi:10.1016/0191-8141(85)90037-9.

Gourley, J. R., T. Byrne, Y.-C. Chan, F. Wu, and R. J. Rau (2007), Fault geometries illuminated from seismicity in central Taiwan: Implications for crustal scale structural boundaries in the northern Central Range, Tectonophysics, 445, 168-185, doi:10.1016/j.tecto.2007.08.013.

Gutenberg, B., and C. A. F. Richter (1956), Earthquake magnitude, intensity, energy, and acceleration, Bull. Seismol. Soc. Am., 46, 105-145.
Harris, R. (2011), The nature of the Banda arc-continent collision in the Timor region, in Arc-Continent Collision, edited by D. Brown and P. D. Ryan, pp. 163-211, Springer, New York.

Hatcher, R. D., and R. T. Williams (1986), Mechanical model for single thrust sheets Part I: Taxonomy of crystalline thrust sheets and their relationships to the mechanical behavior of orogenic belts, Geol. Soc. Am. Bull., 97 975-985, doi:10.1130/0016-7606(1986)97<975:MMFSTS >2.0.CO;2.

Hickman, J. B., D. V. Wiltschko, J.-H. Hung, P. Fang, and Y. Bock (2002), Structure and evolution of the active fold-and-thrust belt of southwestern Taiwan from Global Positioning System analysis, in Geology and Geophysics of an Arc-Continent Collision, Taiwan, edited by T. B. Byrne and C.-S. Liu, Spec. Pap. Geol. Soc. Am., 358, 75-92.

Ho, C.-S. (1988), An introduction to the geology of Taiwan: Explanatory text of the geological map of Taiwan, Cent. Geol. Sur, Taipei.

Hossack, J. R. (1979), The use of balanced cross-sections in the calculation of orogenic contraction: A review, J. Geol. Soc., 136, 705-711, doi:10.1144/gsjgs.136.6.0705

Hsu, Y.-J., S.-B. Yu, M. Simmons, L.-C. Kuo, and H.-Y. Chen (2009), Interseismic crustal deformations in the Taiwan plate boundary zone revealed by GPS observations, seismicity, and earthquake focal mechanisms, Tectonophysics, 479, 4-18, doi:10.1016/j.tecto 2008.11.016.

Huang, C., Y.-C. Chan, J.-C. Hu, J. Angelier, and J.-C. Lee (2008), Detailed surface co-seismic displacement of the 1999 Chi-Chi earthquake in western Taiwan and implication of fault geometry in the shallow subsurface, J. Struct. Geol., 30, 1167-1176, doi:10.1016/j.jsg.2008.06.001.

Huang, C.-S., K.-S. Shea, and M.-M. Chen (2000), Geological map of Taiwan: Sheet 32, Puli, Cent. Geol. Sur, Taipei.

Huang, C.-Y., W.-Y. Wu, C.-P. Chang, S. Tsao, P.-B. Yuan, C.-W. Lin, and K.-Y. Xia (1997), Tectonic evolution of accretionary prism in the arc-continent collision terrane of Taiwan, Tectonophysics, 281, 31-51, doi:10.1016/S0040-1951(97)00157-1

Huang, C.-Y., P.-B. Yuan, C.-W. Lin, T.-K. Wang, and C.-P. Chang (2000), Geodynamic processes of Taiwan arc-continent collision and comparison with analogs in Timor, Papua New Guinea, Urals, and Corsica, Tectonophysics, 325, 1-21, doi:10.1016/S0040-1951(00)00128-1.

Huang, C.-Y., K. Xia, P. B. Yuan, and P.-G. Chen (2001), Structural evolution from Paleogene extension to latest Miocene-Recent arc-continent collision offshore Taiwan: Comparison with on land geology, J. Asian Earth Sci., 19, 619-639, doi:10.1016/367-9120(00)00065-1.

Huang, C.-Y., P.-B. Yuan, and S.-J. Tsao (2006), Temporal and spatial records of active arc-continent collision in Taiwan: A synthesis, Geol. Soc. Am. Bull., 118, 274-288, doi:10.1130/B25527.1

Hung, J.-H., K.-F. Ma, C.-Y. Wang, H. Ito, W. Lin, and E.-C. Yeh (2009), Subsurface structure, physical properties, fault-zone characteristics and stress state in scientific drill holes of Taiwan Chelungpu Fault drilling project, Tectonophysics, 466, 307-321, doi:10.1016/j.tecto.2007.11.014.

Hwang, C., Y.-S. Hsiao, H.-C. Shih, M. Yang, K.-H. Chen, R. Forsberg, and A. V. Olesen (2007), Geodetic and geophysical results from a Taiwan airborne gravity survey: Data reduction and accuracy assessment, J. Geophys. Res., 112, B04407, doi:10.1029/2005JB004220.

Jahn, B.-M., W.-R. Chi, and T.-F. Yui (1992), A Late Permian formation of Taiwan (marbles from Chia-Li well No. 1): $\mathrm{Pb}-\mathrm{Pb}$ isochron and $\mathrm{Sr}$ isotope evidence, and its regional geological significance, J. Geol. Soc. China, $35,193-218$.

Jeng, F.-S., M.-L. Lin, C.-Y. Lu, and K.-P. Huang (2002), Characteristics of seismic energy release of subduction zones-Examples from Taiwan, Eng. Geol., 67, 17-38, doi:10.1016/S0013-7952(02)00107-2.

Johnson, K. M., and P. Segall (2004), Imaging the ramp-décollement geometry of the Chelungpu fault using coseismic GPS displacements from the 1999 Chi-Chi, Taiwan earthquake, Tectonophysics, 378, 123-139, doi:10.1016/j.tecto.2003.10.020.

Jones, R. H., and R. C. Stewart (1997), A method for determining significant structures in a cloud of earthquakes, J. Geophys. Res., 102, 8245-8254, doi:10.1029/96JB03739.

Kao, H., and W.-P. Chen (2000), The Chi-Chi earthquake sequence: Active, out-of-sequence thrust faulting in Taiwan, Science, 288, 2346-2349, doi:10.1126/science.288.5475.2346.

Kaus, B. J. P., C. Steedman, and T. W. Becker (2008), From passive continental margin to mountain belt: Insights from analytical and numerical modeling and application to Taiwan, Phys. Earth Planet. Inter., 171, 235-251, doi:10.1016/j.pepi.2008.06.015.

Kirkpatrick, J. D., Z. K. Shipton, J. P. Evans, S. Micklethwaite, S. J. Lim, and P. McKillop (2008), Strike-slip fault terminations at seismogenic depths: The structure and kinematics of the Glacier Lakes fault, Sierra Nevada United States, J. Geophys. Res., 113, B04304, doi:10.1029/ 2007JB005311.

Kuo-Chen, H., F. T. Wu, and S. W. Roecker (2012), Three-dimensional $\mathrm{P}$ velocity structures of the lithosphere beneath Taiwan from the analysis 
of TAIGER and related seismic data sets, J. Geophys. Res., 117, B06306, doi:10.1029/2011JB009108.

Laubscher, H. P. (1987), Die tektonische Entwicklung der Nordschweitz, Eclogae Geol. Helv., 80, 287-303.

Lee, J.-C., and Y.-C. Chan (2007), Structure of the 1999 Chi-Chi earthquake rupture and interaction of thrust faults in the active fold belt of western Taiwan, J. Asian Earth Sci., 31, 226-239, doi:10.1016/j.jseaes.2006. 07.024 .

Lee, J. C., J. Angelier, and H.-T. Chu (1997), Polyphase history and kinematics of a complex major fault zone in the northern Taiwan mountain belt: The Lishan fault, Tectonophysics, 274, 97-115, doi:10.1016/ S0040-1951(96)00300-9.

Lee, P.-J. (1963), Lithofacies of the Toukoshan-Cholan Formation of western Taiwan, Proc. Geol. Soc. China, 6, 41-50.

Lee, Y.-H., C.-C. Chen, T.-K. Liu, H.-C. Ho, H.-Y. Lu, and W. Lo (2006), Mountain building mechanisms in the southern Central Range of the Taiwan orogenic belt-From accretionary wedge deformation to arccontinent collision, Earth Planet. Sci. Lett., 252, 413-422, doi:10.1016/j.epsl.2006.09.047.

Leever, K. A., R. H. Gabrielsen, J. I. Faleide, and A. Braathen (2011), A transpressional origin for the West Spitsbergen fold-and-thrust belt: Insight from analog modeling, Tectonics, 30, TC2014, doi:10.1029/ 2010TC002753.

Lin, A. T., and A. Watts (2002), Origin of the west Taiwan basin by orogenic loading and flexure of a rifted continental margin, J. Geophys. Res., 107(B9), 2185, doi:10.1029/2001JB000669.

Lin, A. T., A. Watts, and P. Hesselbo (2003), Cenozoic stratigraphy and subsidence history of the South China Sea margin in the Taiwan region, Basin Res., 15, 453-478, doi:10.1046/j.1365-2117.2003.00215.x.

Lin, C.-H. (2007), Tomographic image of crustal structures across the Chelungpu fault: Is the seismogenic layer structure- or depth-dependent?, Tectonophysics, 443, 271-279, doi:10.1016/j.tecto.2007.01.022.

Lin, K.-C., J.-C. Hu, K.-E. Ching, J. Angelier, R.-J. Rau, S.-B. Yu, C.-H. Tsai, T.-C. Shin, and M.-H. Huang (2010), GPS crustal deformation, strain rate, and seismic activity after the 1999 Chi-Chi earthquake in Taiwan, J. Geophys. Res., 115, B07404, doi:10.1029/2009JB006417.

Liu, T.-K., S. Hsieh, Y.-G. Chen, and W.-S. Chen (2001), Thermokinematic evolution of the Taiwan oblique-collision mountain belt as revealed by zircon fission track dating, Earth Planet. Sci. Lett., 186 , 45-56, doi:10.1016/S0012-821X(01)00232-1.

Lo, W., and C.-N. Yang (2002), Geological map of Taiwan, sheet 26, Wushe, scale 1:50,000, Cent. Geol. Surv., Taipei.

Malavieille, J., and G. Trullenque (2009), Consequences of continental subduction on forearc basin and accretionary wedge deformation in SE Taiwan: Insights from analogue modeling, Tectonophysics, 466, 377-394, doi:10.1016/j.tecto.2007.11.016.

Manatschal, G. (2004), New models for evolution of magma-poor rifted margins based on a review of data and concepts from West Iberia and the Alps, Int. J. Earth Sci., 93, 432-466, doi:10.1007/s00531-0040394-7.

McIntosh, K., Y. Nakamura, T.-K. Wang, R.-C. Shih, A. Chen, and C.-S. Liu (2005), Crustal-scale seismic profiles across Taiwan and the western Philippine Sea, Tectonophysics, 401, 23-54, doi:10.1016/ j.tecto.2005.02.015

McKenzie, D. (1978), Some remarks on the development of sedimentary basins, Earth Planet. Sci. Lett., 40, 25-32, doi:10.1016/0012-821X(78) 90071-7.

Mohn, G., G. Manatschal, O. Müntener, M. Beltrando, and E. Masini (2010), Unravelling the interaction between tectonic and sedimentary processes during lithospheric thinning in the Alpine Tethys margins, Int. J. Earth Sci., Suppl 1, 99, 75-101, doi:10.1007/s00531-010-0566-6.

Mouthereau, F., and O. Lacombe (2006), Inversion of the Paleogene Chinese continental margin and thick-skinned deformation in the Western Foreland of Taiwan, J. Struct. Geol., 28, 1977-1993, doi:10.1016/ j.jsg.2006.08.007.

Mouthereau, F., and C. Petit (2003), Rheology and strength of the Eurasian continental lithosphere in the foreland of the Taiwan collision belt: Constraints from seismicity, flexure, and structural styles, J. Geophys. Res., 108(B11), 2512, doi:10.1029/2002JB002098.

Mouthereau, F., O. Lacombe, B. Deffontaines, J. Angelier, H.-T. Chu, and C.-T. Lee (1999), Quaternary transfer faulting and belt front deformation at Pakuashan (western Taiwan), Tectonics, 18, 215-230, doi:10.1029/ 1998 TC 900025 .

Mouthereau, F., O. Lacombe, B. Deffontaines, J. Angelier, and S. Brusset (2001), Deformation history of the southwestern Taiwan foreland thrus belt: Insights from tectono-sedimentary analyses and balanced crosssections, Tectonophysics, 333, 293-318, doi:10.1016/S0040-1951(00) 00280-8.
Mouthereau, F., B. Deffontaines, O. Lacombe, and J. Angelier (2002), Variations along the strike of the Taiwan thrust belt: Basement control on structural style, wedge geometry, and kinematics, in Geology and Geophysics of an Arc-Continent Collision, Taiwan, edited by T. B. Byrne and C.-S. Liu, Spec. Pap. Geol. Soc. Am., 358, 31-54.

Mouthereau, F., C. Fillon, and K.-F. Ma (2009), Distribution of strain rates in the Taiwan orogenic wedge, Earth Planet. Sci. Lett., 284, 361-385, doi:10.1016/j.epsl.2009.05.005

Murphy, J. B., J. W. F. Waldron, D. J. Kontak, G. Pe-Piper, and D. J. W. Piper (2011), Minas Fault Zone: Late Paleozoic history of an intra-continental orogenic transform fault in the Canadian Appalachians, J. Struct. Geol., 33, 312-328, doi:10.1016/j.jsg.2010.11.012.

Namson, J. (1981), Structure of the western foothills belt, Miaoli-Hsinchu area, Taiwan. 1. Southern part, Pet. Geol. Taiwan, 18, 31-51.

Narr, W., and J. Suppe (1994), Kinematics of basement-involved compressive structures, Am. J. Sci., 294, 802-860, doi:10.2475/ajs.294.7.802.

Oncken, O., C. von Winterfeld, and U. Dittmar (1999), Accretion of a rifted passive margin: The Late Paleozoic Rhenohercynian fold and thrust belt (Middle European Variscides), Tectonics, 18, 75-91, doi:10.1029/ 98TC02763

Perez-Estaun, A., J. Alvarez-Marron, D. Brown, V. Puchkov, Y. Gorozhanina and V. Baryshev (1997), Along-strike structural variations in the foreland thrust and fold belt of the southern Urals, Tectonophysics, 276, 265-280, doi:10.1016/S0040-1951(97)00060-7.

Rau, R.-J., and F. T. Wu (1995), Tomographic imaging of lithospheric structures under Taiwan, Earth Planet. Sci. Lett., 133, 517-532, doi:10.1016/0012-821X(95)00076-O.

Reston, T., and G. Manatschal (2011), Rifted margins: Building blocks of later collision, in Arc-Continent Collision, edited by D. Brown and P. D. Ryan, pp. 3-21, Springer, New York.

Reston, T., C. M. Krawczyk, and D. Klaeschen (1996), The S reflector west of Galica (Spain): Evidence from prestack depth migration for detachment faulting during continental breakup, J. Geophys. Res., 101, 8075-8091, doi:10.1029/95JB03466.

Rodgers, J. (1987), Chains of basement uplifts within cratons marginal to orogenic belts, Am. J. Sci., 287, 661-692, doi:10.2475/ajs.287.7.661.

Sakaguchi, A., A. Yanagihara, K. Ujiie, H. Tanaka, and M. Kameyama (2007), Thermal maturity of a fold-thrust belt based on vitrinite reflectance analysis in the Western Foothills complex, western Taiwan, Tectonophysics, 443, 220-232, doi:10.1016/j.tecto.2007.01.017.

Schmidt, C. J., J. M. O'Neill, and W. C. Brandon (1988), Influence of Rocky Mountain foreland uplifts on the development of the frontal fold and thrust belt, southwestern Montana, in Interaction of the Rocky Mountain Foreland and Cordilleran Thrust Belt, edited by C. J. Schmidt and W. J. Perry, Mem. Geol. Soc. Am., 171, 171-201.

Shaw, C.-L. (1996), Stratigraphic correlation and isopach maps of the Western Taiwan Basin, Terr. Atmos. Oceanic Sci., 7, 333-360.

Shin, T.-C. (1993), The calculation of local magnitude from the simulated Wood-Anderson seismograms of the short-period seismograms in Taiwan area, Terr. Atmos. Oceanic Sci., 4, 155-170.

Shyu, J. B. H., K. Sieh, Y.-G. Chen, R.-Y. Chuang, Y. Wang, and L.-H. Chung (2008), Geomorphology of the southernmost Longitudinal Valley Fault: Implications for evolution of the active suture of eastern Taiwan, Tectonics, 27, TC1019, doi:10.1029/2006TC002060.

Simoes, M., and J. P. Avouac (2006), Investigating the kinematics of mountain building in Taiwan from the spatiotemporal evolution of the foreland basin and western foothills, J. Geophys. Res., 111, B10401, doi:10.1029/ 2005JB004209.

Simoes, M., J. P. Avouac, Y.-G. Chen, A. K. Singkvi, C.-Y. Wang, M. Jaiswal, Y.-C. Chan, and S. Bernard (2007a), Kinematic analysis of the Pakuashan fault tip fold, west central Taiwan: Shortening rate and age of folding inception, J. Geophys. Res., 112, B03S14, doi:10.1029/ 2005JB004198

Simoes, M., J. P. Avouac, O. Beyssac, B. Goffé, K. A. Farley, and Y.-G. Chen (2007b), Mountain building in Taiwan: A thermokinematic model, J. Geophys. Res., 112, B11405, doi:10.1029/2006JB004824.

Simoes, M., O. Beyssac, and Y.-G. Chen (2012), Late Cenozoic metamorphism and mountain building in Taiwan: A review, J. Asian Earth Sci., 46, 92-119, doi:10.1016/j.jseaes.2011.11.009.

Sung, Q.-C., Y.-C. Chen, H. Tsai, Y.-G. Chen, and W.-S. Chen (2000), Comparison study on the coseismic deformation of the 1999 Chi-Chi earthquake and long-term stream gradient changes along the Chelungpu fault in central Taiwan, Terr. Atmos. Oceanic Sci., 11, 735-750.

Suppe, J. (1976), Décollement folding in southwestern Taiwan, Pet. Geol. Taiwan, 13, 25-35.

Suppe, J. (1980), A retrodeformable cross section of northern Taiwan, Proc. Geol. Soc. China, 23, 46-55.

Suppe, J. (1981), Mechanics of mountain building and metamorphism in Taiwan, Geol. Soc. China Mem, 4, 67-89. 
Sylvester, A. G. (1988), Strike-slip faults, Geol. Soc. Am. Bull., 100, 1666-1703, doi:10.1130/0016-7606(1988)100<1666:SSF>2.3.CO;2.

Teng, L.-S. (1987), Stratigraphic records of the late Cenozoic Penglai Orogeny of Taiwan, Acta Geol. Taiwanica, 25, 205-224.

Teng, L.-S. (1990), Geotectonic evolution of the late Cenozoic arccontinent collision in Taiwan, Tectonophysics, 183, 57-76, doi:10.1016/ 0040-1951(90)90188-E.

Teng, L.-S. (1992), Geotectonic evolution of Tertiary continental margin basins of Taiwan, Pet. Geol. Taiwan, 27, 1-19.

Teng, L.-S., and A.-T. Lin (2004), Cenozoic tectonics of the China continental margin; Insights from Taiwan, in Aspects of the Tectonic Evolution of China, edited by J. Malpas et al., Geol. Soc. Spec. Publ., 226, 313-332.

Teng, L.-S., Y. Wang, C.-H. Tang, C.-Y. Huang, T.-C. Huang, M.-S. Yu, and A. Ke (1991), Tectonic aspects of the Paleogene depositional basin of northern Taiwan, Proc. Geol. Soc. China, 34, 313-336.

Tillman, K. S., and T. B. Byrne (1995), Kinematic analysis of the Taiwan slate belt, Tectonics, 14, 322-341, doi:10.1029/94TC02451.

Ustaszewski, K., Y.-M. Wu, J. Suppe, H.-H. Huang, C.-H. Chang, and S. Carena (2012), Crust-mantle boundaries in the Taiwan-Luzon arccontinent collision system determined from local earthquake tomography and 1D models: Implications for the mode of subduction polarity reversal, Tectonophysics, doi:10.1016/j.tecto.2011.12.029, in press.

Walcott, R. I. (1998), Modes of oblique compression: Late Cenozoic tectonics of the South Island of New Zealand, Rev. Geophys., 36, 1-26, doi:10.1029/97RG03084.

Wang, C.-Y., C.-L. Li, F.-C. Su, M.-T. Leu, M.-S. Wu, S.-H. Lai, and C.-C. Chern (2002), Structural mapping of the 1999 Chi-Chi earthquake fault, Taiwan, by seismic reflection methods, Terr. Atmos. Oceanic Sci., 13, 211-226.

Wang, C.-Y., S.-Y. Kuo, W.-L. Shyu, and J.-W. Hsiao (2003), Investigating near surface structures under the Changhua fault, west-central Taiwan by the reflection seismic method, Terr. Atmos. Oceanic Sci., 14, 343-367.

Wang, H.-L., H.-W. Chen, and L. Zhu (2010), Constraints on average Taiwan reference Moho discontinuity model-Receiver function analysis using BATS data, Geophys. J. Int., 183, 1-19.

Wibberley, C. A. J. (1997), A mechanical model for the reactivation of compartmental faults in basement thrust sheets, Muzelle region, western Alps, J. Geol. Soc., 154, 123-128, doi:10.1144/gsjgs.154.1.0123.

Woodward, N. B. (1988), Primary and secondary basement controls on thrust sheet geometries, in Interaction of the Rocky Mountain Foreland and Cordilleran Thrust Belt, edited by C. J. Schmidt and W. J. Perry, Mem. Geol. Soc. Am., 171, 353-366.

Wu, F., R.-J. Rau, and D. Salzberg (1997), Taiwan Orogeny; thin-skinned or lithospheric collision? An introduction to active tectonics in Taiwan, Tectonophysics, 274, 191-220, doi:10.1016/S0040-1951(96)00304-6.

Wu, F., C.-S. Chang, and Y. M. Wu (2004), Precisely relocated hypocentres, focal mechanisms and active orogeny in central Taiwan, in Aspects of the Tectonic Evolution of China, edited by J. Malpas et al., Geol. Soc. Spec. Publ., 226, 333-354.

Wu, Y.-M., C.-H. Chang, N.-C. Hsiao, and F.-T. Wu (2003), Relocation of the 1998 Rueyli, Taiwan, earthquake sequence using three-dimensions velocity structure with stations corrections, Terr. Atmos. Oceanic Sci., $14,421-430$.

Wu, Y.-M., C.-H. Chang, L. Zhao, J. B. H. Shyu, Y.-G. Chen, K. Sieh, and J. P. Avouac (2007), Seismic tomography of Taiwan: Improved constraints from a dense network of strong motion stations, J. Geophys. Res., 112, B08312, doi:10.1029/2007JB004983.

Wu, Y.-M., C.-H. Chang, L. Zhao, T.-L. Teng, and M. Nakamura (2008a), A comprehensive relocation of earthquakes in Taiwan from 1991 to 2005, Bull. Seismol. Soc. Am., 98, 1471-1481, doi:10.1785/0120070166.

Wu, Y.-M., L. Zhao, C. H. Chang, and Y. J. Hsu (2008b), Focal mechanism determination in Taiwan by genetic algorithm, Bull. Seismol. Soc. Am., 98, 651-661, doi:10.1785/0120070115.

Wu, Y.-M., J. B. H. Shyu, C.-H. Chang, L. Zhao, M. Nakamura, and S.-K. Hsu (2009), Improved seismic tomography offshore northeastern Taiwan: Implications for subduction and collision processes between Taiwan and the southernmost Ryukyu, Geophys. J. Int., 178(2), 1042-1054, doi:10.1111/j.1365-246X.2009.04180.x.

Wu, Y.-M., Y.-J. Hsu, C.-H. Chang, L.-S. Teng, and M. Nakamura (2010), Temporal and spatial variation of stress field in Taiwan from 1991 to 2007: Insights from comprehensive first motion focal mechanism catalog, Earth Planet. Sci. Lett., 298, 306-316, doi:10.1016/j.epsl.2010.07.047.

Yamato, P., F. Mouthereau, and E. Burov (2009), Taiwan mountain building: Insights from 2-D thermomechanical modelling of a rheologically stratified lithosphere, Geophys. J. Int., 176, 307-326, doi:10.1111 j.1365-246X.2008.03977.x.

Yanites, B. J., G. E. Tucker, K. J. Mueller, Y.-G. Chen, T. Wilcox, S.-Y. Huang, and K.-W. Shi (2010), Incision and channel morphology across active structures along the Peikang River, central Taiwan: Implications for the importance of channel width, Geol. Soc. Am. Bull., 122, 1192-1208, doi:10.1130/B30035.1.

Yen, H.-Y., Y.-H. Yeh, and F. T. Wu (1998), Two-dimensional crustal structures of Taiwan from gravity data, Tectonics, 17, 104-111, doi:10.1029/97TC02697.

Yu, S.-B., and L. C. Kuo (2001), Present day crustal motion along the Longitudinal Valley Fault, eastern Taiwan, Tectonophysics, 333, 199-217, doi:10.1016/S0040-1951(00)00275-4.

Yu, S.-B., H. Y. Chen, and L. C. Kuo (1997), Velocity field of GPS stations in the Taiwan area, Tectonophysics, 274, 41-59, doi:10.1016/S00401951(96)00297-1.

Yu, S.-B., Y.-J. Hsu, L. C. Kuo, H.-C. Chen, H.-Y. Chen, and C.-C. Liu (2003), GPS measurement of postseismic deformation following the 1999 Chi-Chi, Taiwan, earthquake, J. Geophys. Res., 108(B11), 2520, doi:10.1029/2003JB002396.

Yue, L.-F., J. Suppe, and J.-H. Hung (2005), Structural geology of a classic thrust belt earthquake: The 1999 Chi-Chi earthquake Taiwan $(\mathrm{Mw}=7.6)$, J. Struct. Geol., 27, 2058-2083, doi:10.1016/j.jsg.2005.05.020.

Yui, T.-F., K. Maki, C.-Y. Lan, T. Hirata, H.-T. Chu, Y. Kon, T.-D. Yokoyama, B.-M. Jahn, and W. G. Ernst (2012), Detrital zircons from the Tananao Metamorphic Complex of Taiwan: Implications for sediment provenance and Mesozoic tectonics, Tectonophysics, 541-543, 31-42, doi:10.1016/j.tecto.2012.03.013. 